\title{
The Varicella-Zoster Virus Immediate-Early 63 protein affects chromatin controlled gene transcription in a cell-type dependent
} manner

\author{
Lionel Habran, Nadia El Mjiyad, Emmanuel Di Valentin, Catherine Sadzot- \\ Delvaux, Sébastien Bontems and Jacques Piette*
}

Address: Virology \& Immunology Unit, GIGA-Research, GIGA B34, University of Liège, B-4000 Liège, Belgium.

Email: Lionel Habran - lionel@ habran.be; Nadia El Mjiyad - nelmjiyad@ulg.ac.be; Emmanuel Di Valentin - edivalentin@ulg.ac.be; Catherine Sadzot-Delvaux - csadzot@ulg.ac.be; Sébastien Bontems - sbontems@ulg.ac.be; Jacques Piette* - jpiette@ulg.ac.be

* Corresponding author

Published: 30 October 2007

BMC Molecular Biology 2007, 8:99 doi:10.1 186/1471-2199-8-99

This article is available from: http://www.biomedcentral.com/I47I-2199/8/99

(c) 2007 Habran et al; licensee BioMed Central Ltd.

This is an Open Access article distributed under the terms of the Creative Commons Attribution License (http://creativecommons.org/licenses/by/2.0), which permits unrestricted use, distribution, and reproduction in any medium, provided the original work is properly cited.
Received: 12 July 2007

Accepted: 30 October 2007

\begin{abstract}
Background: Varicella Zoster Virus Immediate Early 63 protein (IE63) has been shown to be essential for VZV replication, and critical for latency establishment. The activity of the protein as a transcriptional regulator is not fully clear yet. Using transient transfection assays, IE63 has been shown to repress viral and cellular promoters containing typical TATA boxes by interacting with general transcription factors.

Results: In this paper, IE63 regulation properties on endogenous gene expression were evaluated using an oligonucleotide-based micro-array approach. We found that IE63 modulates the transcription of only a few genes in HeLa cells including genes implicated in transcription or immunity. Furthermore, we showed that this effect is mediated by a modification of RNA POL II binding on the promoters tested and that IE63 phosphorylation was essential for these effects. In MeWo cells, the number of genes whose transcription was modified by IE63 was somewhat higher, including genes implicated in signal transduction, transcription, immunity, and heat-shock signalling. While IE63 did not modify the basal expression of several NF-KB dependent genes such as IL-8, ICAM-I, and IKB $\alpha$, it modulates transcription of these genes upon TNF $\alpha$ induction. This effect was obviously correlated with the amount of p65 binding to the promoter of these genes and with histone $\mathrm{H} 3$ acetylation and HDAC-3 removal.
\end{abstract}

Conclusion: While IE63 only affected transcription of a small number of cellular genes, it interfered with the TNF-inducibility of several NF-KB dependent genes by the accelerated resynthesis of the inhibitor $\mathrm{I} K \mathrm{~B} \alpha$.

\section{Background}

Varicella Zoster Virus (VZV) is the etiological agent of two clinically distinct diseases: varicella (chicken pox) as primary infection and zoster (shingles) after reactivation of latent virus from the dorsal root ganglia. Zoster is usually observed in elderly or immuno-compromised patients [1]. During latency, VZV does not express LAT as other $\alpha$ Herpesvirus do, but viral proteins that are also present during lytic infection [2]. Transcripts from ORF4, 21, 29, 62,63 , and $66[2-8]$, and several of the corresponding pro- 
teins have been detected in latently infected cells [8-12]. A recent study indicated that the expression of latencyrelated VZV genes, like ORF62 and 63, is regulated by epigenetic modifications of chromatin [13].

IE63 is of particular interest in VZV pathogenesis since it is abundantly expressed during acute infection and is the most abundant and most frequently identified of the six VZV gene products expressed during latency (reviewed in [14]). Its cellular localization is quite particular. Indeed, during a lytic infection it localizes mostly in the nucleus and slightly in the cytoplasm while during latency, it concentrates in the cytoplasm $[8-10,15]$. This protein is encoded by ORF63 and ORF70 and is the putative homologue of HSV ICP22. It has an apparent molecular mass of $45 \mathrm{kDa}$ and is present in the virion tegument [16]. Moreover, IE63 interacts with VZV IE62 protein [5,17], is essential or not for VZV replication, depending on the cell-type studied $[5,18,19]$ and critical for the establishment of latency [19]. In addition to regulatory functions, evidences were also provided that ORF63 promotes neuronal cell survival after VZV infection by modulating apopflsfto кis [20]. It has also been recently shown that expression of IE63 in the absence of other viral proteins blocked the antiviral effects of IFN-alpha by inhibiting phosphorylation of the alpha subunit of eukaryotic initiation factor 2 (eIF-2alpha) [21].

The activity of IE63 as a potential transcriptional regulator has been subject to controversy for years. It has been claimed that IE63 played only a minor role in the control of VZV gene expression [22]. However results from our laboratory showing that IE63 is able to down-regulate the expression of VZV immediate early (IE) and early (E) genes as well as heterologous viral and cellular promoters [23] suggest that IE63 has essential functions in the virus infectious cycle. Moreover, these repressive properties were shown to be dependent on the phosphorylation status of the protein $[24,25]$. Others found that IE63 could act as a co-stimulator of IE62 activity on the promoter of the VZV glycoprotein I (gI) [17]. It was alsoshown that IE63 could activate transcription driven by the cellular EF$1 \alpha$ promoter in the absence of other viral proteins in nonneuronal cells [26]. Finally, Desloges et al. added to the list of promoters regulated by IE63 one other heterologous promoter, the human GAPDH promoter [27]. Thus, based on currently published data, the effects of IE63 appear to be pleiotropic depending at least in part of the cell type and the promoter investigated.

The mechanisms by which IE63 could modulate gene transcription was poorly understood before it was shown that IE63 could mediate its repressive properties by disorganizing the pre-initiation complex by interacting with TFIIH, TFIIE, and RNA POL II [23]. In order to better understand the mechanism of action of IE63, we examined its effects on the regulation of cellular genes expression by full genome micro-array analysis in HeLa and MeWo cells infected with a lentivirus allowing the stable expression. We found that IE63 alone affected the transcription of a limited set of human genes. Furthermore, we showed that in HeLa cells the correct phosphorylation of IE63 is essential for the regulatory properties on endogenous promoters. Recently, a micro-array analysis of MRC5 cells infected with a recombinant adenovirus expressing IE63 has been published [28]. In this work, IE63 was shown to down-regulate the heat shock $70 \mathrm{kDa}$ protein gene expression while several histone genes were found up-regulated.

In transient transfection assays, IE63 was demonstrated to down-regulate several cellular NF- $\kappa \mathrm{B}$-responding genes like IL-8 and IL-6 [23]. Surprisingly, these genes were not repressed in our experiments, as demonstrated by both micro-array analysis and real-time PCR. The fact that IE63 had no effect on basal expression of some NF- $\kappa \mathrm{B}$ responsive genes may be due to a problem of promoter accessibility linked to chromatin opening. In order to assess this issue, we measured the expression rate of some of these genes (IL-8, IL-6, ICAM-1, and I $\mathrm{B} \alpha \alpha$ ) in IE63 expressing HeLa cells after treatment with $\mathrm{TNF} \alpha$, a major pro-inflammatory cytokine known to increase chromatin accessibility of several promoters. We demonstrated that IE63 modulated IL-8, ICAM-1, and I $\mathrm{B} \alpha$ expression in response to $\mathrm{TNF} \alpha$ via chromatin remodelling and modification of the recruitment of NF- $\kappa$ B p 65 subunit.

\section{Results \\ Varicella Zoster Virus IE63 protein affects transcription of a small number of genes in HeLa cells}

In order to study the influence of IE63 on human cellular transcription, three independent stable HeLa cell lines expressing IE63 protein were established. The whole genome expression profiles of HeLa cells infected with a recombinant lentivirus expressing VZV ORF63 (HeLaIE63) and of HeLa cells infected with a recombinant lentivirus where IE63 gene was cloned in an inverted orientation (HeLa-Inv) were compared. In the lentivirus vectors used, the VZV gene was controlled by the EFI $\alpha$ promoter and was in frame with the EGPF gene but separated by an IRES region. All infections were carried out with the same multiplicity of infection. As expected, the three HeLa cell lines infected with the LentilE63 (HeLa-IE63) expressed the EGFP protein (lower panel) and a protein of approximately $45 \mathrm{kDa}$ recognized by a mouse monoclonal antibody directed against the VZV ORF63 protein (Fig.1A). IE63 was not detected in the three HeLa cell lines infected with the lentivirus where the ORF63 was cloned in the anti-sense direction (HeLa-Inv, control cells). Virtually $100 \%$ of HeLa cells expressed EGFP as determined by flow 
cytometry analysis (data not shown). Immunofluorescence studies were carried out to evaluate the proportion of HeLa cells expressing IE63 protein, and 100\% of the cells expressing the EGFP protein also expressed IE63 (Fig. 1B).

Because the correct phosphorylation of IE63 was found essential for its repressive properties in transient transfection studies [24,25], HeLa cells stably expressing mutated forms of IE63 were generated : HeLa-IE63-S224/T222A, where two essential CDK1 phosphorylation residues (S224 and T222) were substituted by alanine [24], and HeLa-IE63-Full where all the phosphorylation target residues for CK1, CK2, and CDK1 were substituted by anala- line [24]. The expression level and the proportion of cells expressing the mutated forms of IE63 protein were verified (Fig.1A, and 1B). The regulation properties of these mutated proteins on cellular genes were analyzed by realtime RT-PCR. As shown in Fig. 2, the abolition of phosphorylation drastically reduces the up- or down-regulating properties of IE63 on selected genes demonstrating that phosphorylation is essential for its activity on endogenous promoters.

To control whether IE63 was functional, HeLa cell lines expressing wild-type IE63 were transfected with a plasmid expressing a reporter gene (luciferase) under the control of the VZV DNA polymerase promoter which displayed a
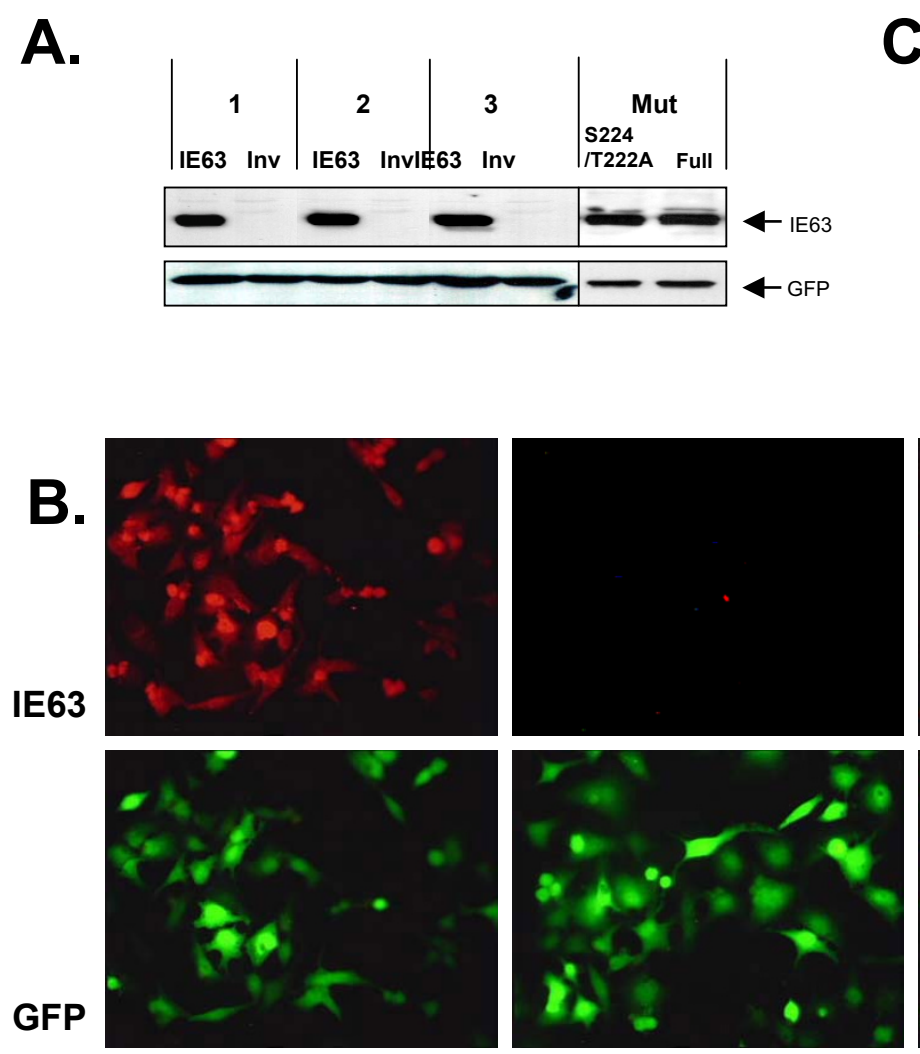

HeLa-IE63HeLa-Inv
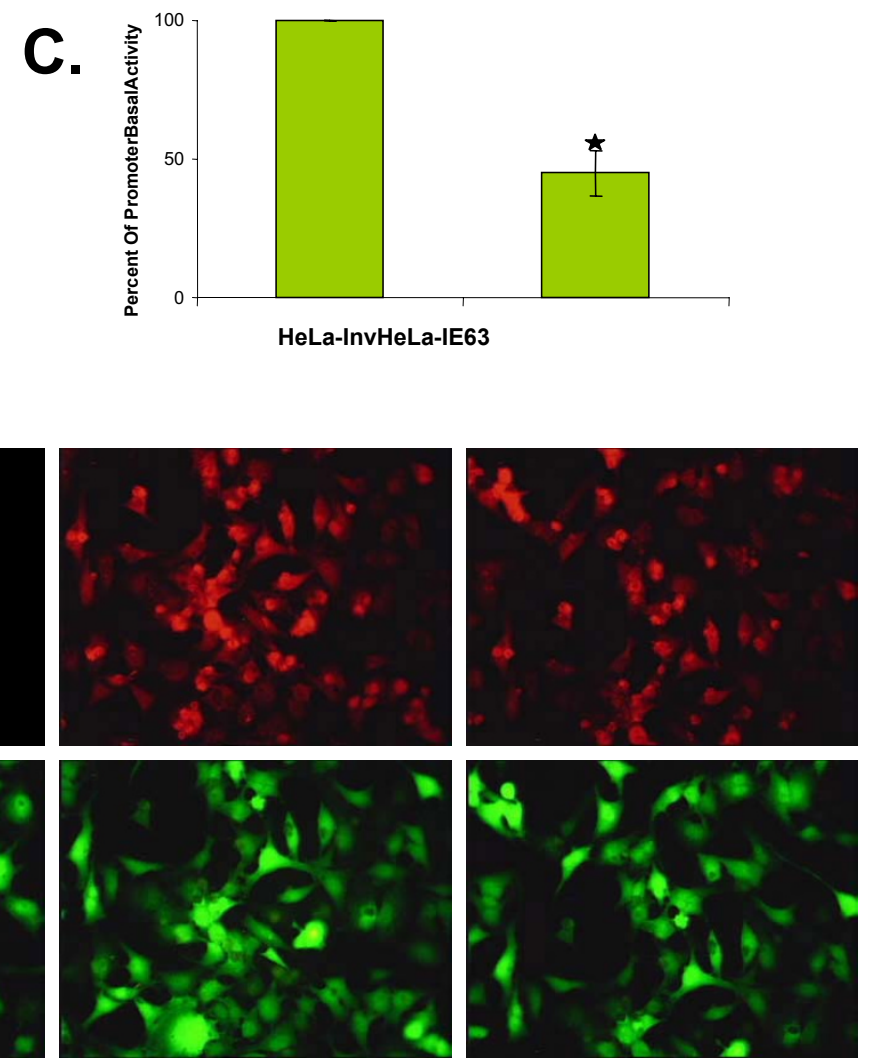

HeLa-IE63-S224/T222AHeLa-IE63-Full

\section{Figure I}

VZV ORF 63 activity and expression by Lentivirus. HeLa cells were infected with the lentivirus (Lenti-IE63, Lenti-Inv, LentiIE63-S224/T222A, Lenti-IE63-Full) in order to generate cell lines that stably express the protein IE63 wild-type (HeLa-IE63), in inverted orientation (HeLa-Inv) or mutated (HeLa-S224/T222A, HeLa-Full). One week after infection, cells were harvested. (A) Cells were lysed in radioimmunoprecipitation assay buffer and used for immunoblotting with mouse monoclonal antibody to the ORF63 protein or with rabbit polyclonal antibody to the EGFP. (B) Forty-eight hours post-seeding, immunostaining analysis was carried out using a monoclonal antibody (9AI2) directed against IE63. Secondary antibody used is conjugated with Texas Red. (C) HeLa cells (HeLa-IE63, and HeLa-Inv) were transfected with I $\mu$ g of pPol-Luc. 24 hours post-transfection, cells were harvested and the reporter gene activity was measured. Results are presented as a percentage of stimulation with respect to the basal expression of the promoter $(=100 \%)$. Data from luciferase assays were collected from six independent transfection experiments. $\rho$-values were calculated using the graphpad quickcalcs software [59]: ${ }^{*}$, significantly different from control ( $p$ value $<0.05)$. 


\section{A.B.}
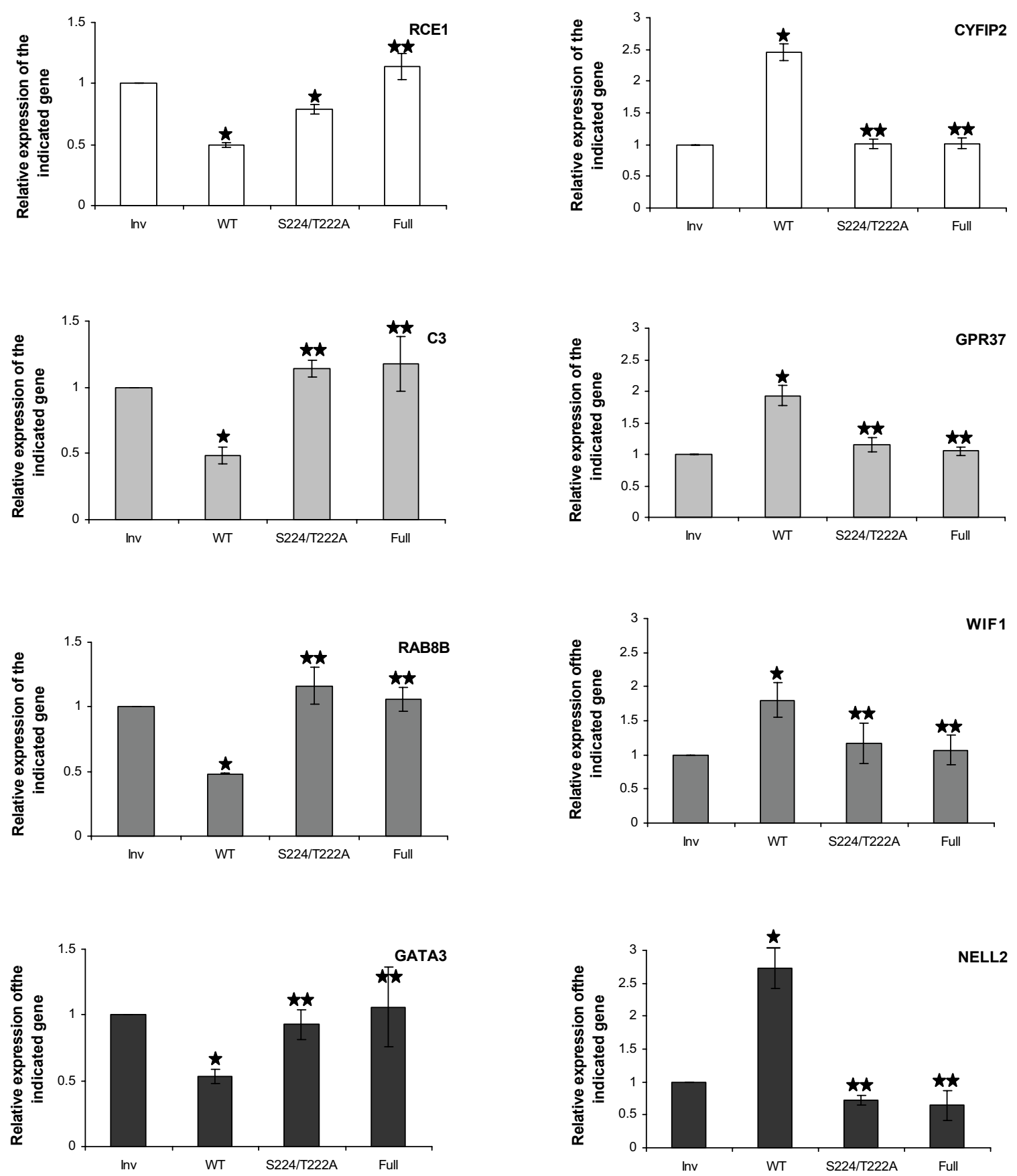

Figure 2

Relative expression of selected cellular genes in HeLa-IE63, HeLa-IE63-S224/T222A, HeLai-IE63-Full versus control cells (HeLa-Inv). mRNA levels (A : RCEI, C3, RAB8B, and GATA3 ; B : CYFIP2, GPR37, WIFI, and NELL2) were determined by quantitative real-time PCR and normalized using the $\beta 2$-microglobuline transcripts. Experiments were done at least in triplicate. Differences ( $n$-fold) between samples were calculated using the standard-curve method and the ${ }^{-}-\Delta \mathrm{Ct}$ method. $\rho$-values were calculated using the graphpad quickcalcs software [59] : *, significantly different from control (Inv; p-value < 0.05); **, not significantly different from control (Inv; $\mathrm{p}$-value $\geq 0.05$ ). 
high basal activity and is known to be down-regulated by IE63 [25]. As shown in Fig. 1C, the basal activity of this promoter is down-regulated up to $50 \%$ in cells expressing IE63, demonstrating that IE63 is functional in these cells.

These cell lines expressing the wild-type IE63 protein were used for a micro-array analysis to delineate the effect of this viral transcription factor on cellular gene expression. For this, we used the U133A GeneChips (Affymetrix) representing 22,277 human genes probes set. Statistical filtering was done to include only genes with a modulation $\rho$ value $<0.05$ (see materials and methods) and found similarly regulated in three independent experiments. As shown in Table 1, 17 genes were up-regulated and 9 were down-regulated in the three HeLa-IE63 cell lines relative to control cells (HeLa-Inv). Gene ontogeny analysis indicated that the predominant categories were signal transduction and transcription.

Real-time RT-PCR experiments were then carried out to confirm the results obtained from micro-array studies. RNA levels of 4 down-regulated (RCE1, C3, RAB8B, and
GATA3; Fig. 2A) and four up-regulated (CYFIP2, GPR37, WIF1, and NELL2; Fig. 2B) genes measured by qRT-PCR confirmed the micro-array data.

\section{IE63 alters the recruitment of the Human RNA polymerase} II on the WIFI and C3 promoters

IE63 was shown to be able to disrupt the transcriptional pre-initiation complex and to interact with several general transcription factors such as RNA POL II, TFIIH, and TFIIE [23]. In order to investigate whether IE63 diminished or enhanced the RNA POL II binding on endogenous human promoters, ChIP assays using antibody to RNA POL II were carried out on promoters either up- (WIF1) or down(C3) regulated by IE63. As shown in Fig. 3, IE63 enhanced the RNA POL II binding on the WIF1 promoter up to 2fold (Fig.3A), whereas RNA POL II binding was significantly decreased by IE63 on the C3 promoter (Fig.3B).

In conclusion, the results presented above showed that IE63 could modulate either positively or negatively the transcription on a restricted number of endogenous pro-

Table I: Genes induced or repressed in HeLa-IE63 cells compared with control cells (Hela-Inv).

\begin{tabular}{|c|c|c|c|c|}
\hline Affimetrix designation & Entrez gene no. & Fold Induction & Gene Symbol & Description \\
\hline \multicolumn{5}{|l|}{ Signal transduction } \\
\hline 20963I_s_at & 2861 & 2.333 & GPR37 & G protein-coupled recept 37 (endoth recept type B-like) \\
\hline 2047I2_at & 11197 & 2.192 & WIFI & WNT inhibitory factor I \\
\hline 210095_s_at & 3486 & 1.911 & IGFBP3 & insulin-like growth factor binding protein 3 \\
\hline 203474_at & 10788 & 1.654 & IQGAP2 & IQ motif containing GTPase activating protein 2 \\
\hline 209869_at & 150 & 1.603 & ADRA2A & Adrenergic, alpha-2A-, recept/adrenergic, alpha-2A-, recept \\
\hline 219210_s_at & 51762 & 0.534 & RAB8B & Member RAS oncogene family \\
\hline \multicolumn{5}{|l|}{ Transcription } \\
\hline 213906_at & 4603 & 1.677 & MYBLI & v-myb myeloblastosis viral oncogene homolog (avian)-like I \\
\hline 209604_s_at & 2625 & 0.548 & GATA3 & GATA binding protein 3 \\
\hline 215685_s_at & 1746 & 0.507 & $\mathrm{DLX} 2$ & distal-less homeo box 2 \\
\hline \multicolumn{5}{|l|}{ Immunity } \\
\hline 217767_at & 718 & 0.507 & $\mathrm{C} 3$ & complement component 3 \\
\hline \multicolumn{5}{|l|}{ Intracellular organelle } \\
\hline 212223_at & 3423 & 1.7 & IDS & Iduronate 2-sulfatase (Hunter syndrome) \\
\hline 203397_s_at & 2591 & 1.579 & GALNT3 & UDP-N-acetyl-alpha-D-galactosamine(GalNAc-T3) \\
\hline 202843_at & 4189 & 1.56 & DNAJB9 & DnaJ (Hsp40) homolog, subfamily B, member 9 \\
\hline 205830_at & 1047 & 1.648 & CLGN & Calmegin \\
\hline 205333_s_at & 9986 & 0.38 & RCEI & RCEI homolog, prenyl protein protease (S. cerevisiae) \\
\hline 21III3_s_at & 9619 & 0.588 & $\mathrm{ABCGI}$ & ATP-binding cassette, sub-family G (WHITE), member I \\
\hline \multicolumn{5}{|l|}{ Other/Unclassified } \\
\hline 215785_s_at & 26999 & 2.59 & CYFIP2 & Cytoplasmic FMRI interacting protein 2 \\
\hline 221901_at & 85352 & 1.892 & KIAAI 644 & KIAAI644 protein \\
\hline 208567_s_at & 3768 & 1.889 & $\mathrm{KCNJ} / 2$ & Potassium inwardly-rectifying channel, subfamily J, member 12 \\
\hline 220393_at & 51557 & 1.864 & GLULD I & Glutamate-ammonia ligase domain containing I \\
\hline 203413_at & 4753 & 1.833 & NELL2 & NEL-like 2 (chicken) \\
\hline 215783_s_at & 249 & 1.67 & ALPL & Alkaline phosphatase, liver/bone/kidney \\
\hline 212158_at & 6383 & 1.668 & SDC2 & Syndecan 2 \\
\hline 213629_x_at & 4494 & 0.582 & MTIF & Metallothionein IF \\
\hline 209946_at & 7424 & 0.579 & VEGFC & Vascular endothelial growth factor C \\
\hline 211066_x_at & $1340 \mid 4$ & 0.559 & Protocad & Protocadherin gamma subfamily $A, B$ and $C$ \\
\hline
\end{tabular}



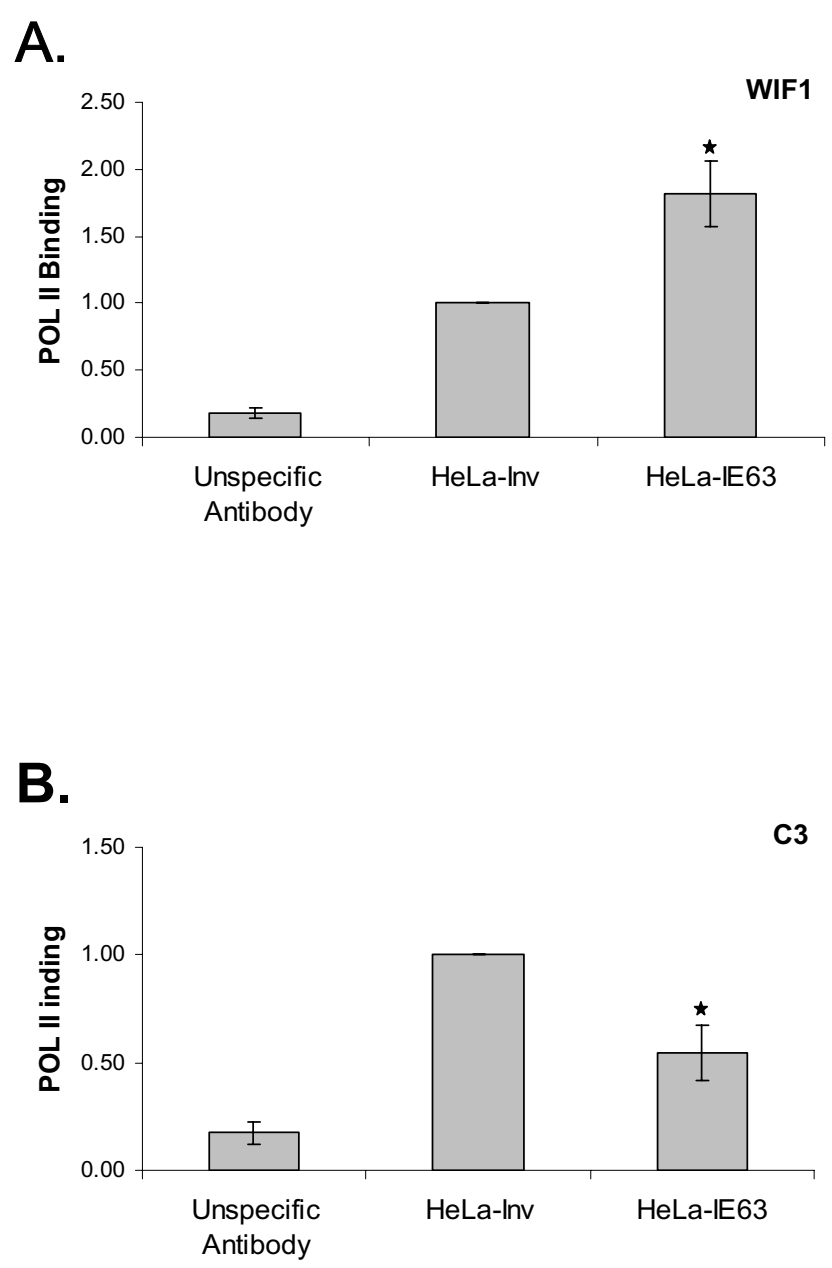

Figure 3

RNA polymerase II recruitment on selected cellular genes in HeLa cells expressing or not IE63. ChIP assay using RNA polymerase II antibody or unspecific antibody (lane I) was performed on total cell lysates. Real-time PCR amplification of a 100 bp fragment from the WIFI (A), and C3 (B) promoter encompassing [59] the transcription initiation site was carried out. $\rho$-values were calculated using the graphpad quickcalcs software [59]: *, significantly different from control (Inv; p-value < 0.05).

moters and this effect required its proper phosphorylation by several cellular kinases.

\section{The effect of IE63 on human gene expression is cell-type dependent}

It has been recently shown that IE63 could modulate a different set of genes when expressed in MRC-5 cells [28]. We then decided to generate MeWo cells stably expressing IE63 in order to determine whether the modulation of gene expression is cell-type dependent. MeWo cells were then infected with the same lentivirus as above. As observed in HeLa cells, the proportion of cells expressing IE63 protein was almost $100 \%$ (data not shown). As shown in Fig. 4A, the expression level of IE63 is similar in the three independent MeWo cell lines generated. Microarray analysis showed that the number of genes affected by IE63 was much higher in this cell-type than in HeLa cells (Table 2). Twenty-one genes were up-regulated and 75 genes were down-regulated more than 2-fold in MeWo-IE63 cells compared to control cells (Table 2). Gene ontogeny analysis indicated that the predominant categories were signal transduction, genes involved in transcription, which were all down-regulated, immunity/ inflammation, chromatin, and 3 members of the heat shock protein 70 (HSP70) family. Real time RT-PCR experiments confirmed the results obtained with 2 up-regulated genes (HLA-DRB1, and MCP-1) and 2 down-regulated genes (TRAF1, and HSPA6) (Fig. 4B).

\section{IE63 modulates gene transcription induced by TNF $\alpha$}

Previous works from our laboratory have shown that transiently expressed IE63 is able to down-regulate several cellular NF-KB-responding genes like IL-8 and IL-6 [23]. Surprisingly, the basal expression level of these genes was not repressed in our experiments, as demonstrated by both micro-array analysis (Table 1 and 2) and real-time RT-PCR (Fig. 5). We also investigated the expression pattern of two other NF-kB-responding genes, ICAM-1 and I $\mathrm{K} \mathrm{\alpha} \alpha$, and we showed that the basal expression of these genes was not altered by IE63. The fact that IE63 had no effect on basal expression of some NF- $\kappa$ B responsive genes may be due to a problem of promoter accessibility linked to chromatin. In order to assess this issue, we measured the transcription level of these genes (IL-8, IL-6, ICAM-1, and IКB $\alpha$ ) in IE63 expressing HeLa cells after treatment with TNF $\alpha$, a cytokine known to increase chromatin accessibility of several genes. Once HeLa cells were stimulated by TNF $\alpha$ for increasing times (from 0 to $2 \mathrm{~h}$ ), it turned out that the presence of IE63 reduced the TNF $\alpha$-mediated expression of IL-8, IL-6, and ICAM-1 (Fig. 6A). Surprisingly, the transcription of ІкB $\alpha$ gene was selectively increased by the presence of IE63 (Fig.6A). This unexpected result was confirmed by Western blot analysis. For this, HeLa cells expressing or not IE63 were treated for increasing times (from 0 to $2 \mathrm{~h}$ ) with TNFa at a final concentration of $200 \mathrm{U} / \mathrm{mL}$. As shown in Fig. 6B, in control HeLa cells a complete I $\mathrm{K} B \alpha$ degradation could be observed after 15 min before observing its resynthesis after $60 \mathrm{~min}$. In IE63 expressing HeLa cells, a complete I $\mathrm{B} \alpha \alpha$ degradation could also be observed $15 \mathrm{~min}$ after $\mathrm{TNF} \alpha$ addition, but its resynthesis could be observed as soon as 30 min demonstrating that the presence of IE63 accelerated the replenishment of the IкB $\alpha$ pool.

The phosphorylation status of IE63 was shown to be crucial for influencing the TNF $\alpha$-mediated gene transcrip- 
Table 2: Genes induced or repressed in MeWo-IE63 cells compared with control cells (MeWo-Inv).

\begin{tabular}{|c|c|c|c|c|}
\hline Affimetrix designation & Entrez gene no. & Fold Induction & Gene Symbol & Description \\
\hline \multicolumn{5}{|l|}{ Signal Transduction } \\
\hline 204425_at & 393 & 0.50 & ARHGAP4 & Rho GTPase activating protein 4 \\
\hline 204736_s_at & 1464 & 0.50 & CSPG4 & chondroitin sulfate proteaoglycan 4 \\
\hline 206028_s_at & $1046 \mid$ & 0.50 & MERTK & c-mer proto-oncogene tyrosine kinase \\
\hline 206374_at & 1850 & 0.50 & DUSP8 & dual specificity phosphatase 8 \\
\hline 213221_s_at & 23235 & 0.50 & KIAA078 I & KIAA078I protein \\
\hline 206359_at & 9021 & 0.38 & SSI-3 & STAT induced STAT inhibitor 3 \\
\hline 202328_s_at & 5310 & 0.33 & PKDI & polycystic kidney disease I (autosomal dominant) \\
\hline \multicolumn{5}{|l|}{ Transcription } \\
\hline 201328_at & 2114 & 0.50 & ETS2 & avian erythroblastosis virus E26 oncogene homolog 2 \\
\hline 213668_s_at & 6659 & 0.50 & sox4 & SRY (sex determining region Y)-box 4 \\
\hline 21393|_at & 3398 & 0.50 & ID2 & $\begin{array}{l}\text { inhibitor of DNA binding } 2 \text {, dominant negative helix-loop- } \\
\text { helix protein }\end{array}$ \\
\hline 215012_at & 26036 & 0.47 & KIAA0576 & KIAA0576 protein \\
\hline 31637_s_at & 732801 & 0.47 & Rev-ErbAalpha & Rev-ErbAalpha \\
\hline 203873_at & 6594 & 0.44 & SMARCAI & $\begin{array}{l}\text { Human global transcription activator homologous sequence } \\
\text { mRNA }\end{array}$ \\
\hline 202672_s_at & 467 & 0.41 & ATF3 & activating transcription factor 3 \\
\hline 210426_x_at & 6095 & 0.41 & RORA & $\begin{array}{l}\text { Human orphan hormone nuclear receptor RORalphal } \\
\text { mRNA }\end{array}$ \\
\hline 20286I_at & 5187 & 0.38 & PERI & Homo sapiens period (Drosophila) homolog I \\
\hline \multicolumn{5}{|c|}{ Immunity/Inflamation } \\
\hline 215193_x_at & 3125 & 2.64 & HLA-DRB I & MHC class II antigen \\
\hline 216598_s_at & 6347 & 2.46 & MCP-I & monocyte chemotactic protein \\
\hline 206569_at & 11009 & 2.14 & STI6 & Homo sapiens suppression of tumorigenicity 16 \\
\hline 211990_at & 3113 & 2.14 & HLA-DPAI & MHC class II DPw3-alpha-I chain mRNA \\
\hline 208894_at & 3122 & 2.00 & HLA-DRA & MHC class II HLA-DR-alpha \\
\hline 209312_x_at & 3123 & 2.00 & HLA-DRB I & HLA-DRB (MHC class II antigen) \\
\hline 206026_s_at & 7130 & 0.50 & TNFAIP6 & tumor necrosis factor, alpha-induced protein 6 \\
\hline 209447_at & 23345 & 0.50 & 8B7 & lymphocyte membrane associated protein \\
\hline 2|420I_x_at & 7916 & 0.47 & D6S5 IE & HLA-B associated transcript-2 \\
\hline 207850_at & 2921 & 0.44 & GRO3 & GRO3 oncogene \\
\hline 217028_at & 7852 & 0.38 & CXCR4 & receptor CXCR4 \\
\hline 205599_at & 7185 & 0.35 & TRAF I & TNF receptor-associated factor I \\
\hline 203665_at & 3162 & 0.35 & HMOXI & heme oxygenase (decycling) I \\
\hline \multicolumn{5}{|c|}{ Intracellular organelle } \\
\hline 217452_s_at & 8707 & 3.73 & B3GALT2 & $\begin{array}{l}\text { 2-acetamido-2-deoxy-D-glucose3beta- } \\
\text { galactosyltransferase }\end{array}$ \\
\hline 205069_s_at & 23092 & 2.83 & KIAA062I & KIAA062I protein \\
\hline 219250_s_at & 23767 & 2.30 & FLRT3 & FLRT3 (fibronectin leucine rich transmembrane protein 3) \\
\hline 211205_x_at & 8394 & 2.14 & PIP5KIA & $\begin{array}{l}68 \text { kDa type I phosphatidylinositol-4-phosphate5-kinase } \\
\text { alpha }\end{array}$ \\
\hline 205547_s_at & 6876 & 2.00 & TAGLN & transgelin \\
\hline 204293_at & 6448 & 0.50 & SGSH & $\mathrm{N}$-sulfoglucosamine sulfohydrolase \\
\hline 209893_s_at & 2526 & 0.50 & FUT4 & ELAM-I ligand fucosyltransferase \\
\hline 205830_at & 1047 & 0.38 & CLGN & Homo sapiens calmegin \\
\hline 207949_s_at & 3382 & 0.33 & ICAI & islet cell autoantigen I (69 kD) \\
\hline 21434I_at & 8906 & 0.02 & APIG2 & adaptor-related protein complex I, gamma 2 subunit \\
\hline \multicolumn{5}{|l|}{ Chromatin } \\
\hline 212257_s_at & 6595 & 2.00 & SMARCA2 & $\begin{array}{l}\text { SWISNF related actin dependent regulator of chromatin, } s f \\
\mathrm{a}, \mathrm{mb} 2\end{array}$ \\
\hline \multicolumn{5}{|l|}{ Heat-Shock } \\
\hline 20258I_at & 3304 & 0.50 & HSPAIB & heat shock $70 \mathrm{kD}$ protein IB \\
\hline 202843_at & 4189 & 0.47 & MDG I & microvascular endothelial differentiation gene I \\
\hline 217911_s_at & 9531 & 0.47 & BAG3 & BCL2-associated athanogene 3 \\
\hline 117_at & 3311 & 0.27 & HSP70B & HSP70B Human heat-shock protein HSP70B gene \\
\hline 213418_at & 3310 & 0.22 & HSPA6 & heat shock 70 kD protein 6 (HSP70B) \\
\hline \multicolumn{5}{|l|}{ Other/Unclassified } \\
\hline 204730_at & 9783 & 5.66 & KIAA0237 & KIAA0237 gene product \\
\hline
\end{tabular}


Table 2: Genes induced or repressed in MeWo-IE63 cells compared with control cells (MeWo-Inv). (Continued)

\begin{tabular}{|c|c|c|c|c|}
\hline 20602I_at & 54581 & 3.03 & SCAND2 & SCAN domain-containing 2 \\
\hline 222108_at & 347902 & 2.83 & AMIGO-2 & amphoterin-induced protein 2 precursor \\
\hline 218332_at & 55859 & 2.64 & HBEX2 & hypothalamus protein \\
\hline 214079_at & 10901 & 2.30 & SDR2 & dehydrogenase/reductase (SDR family) member 2 \\
\hline 208282_x_at & 57055 & 2.00 & DAZ2 & deleted in azoospermia 2 \\
\hline 205960_at & 5166 & 2.00 & PDK4 & Homo sapiens pyruvate dehydrogenase kinase, isoenzyme 4 \\
\hline 21|8|4_s_at & 9134 & 2.00 & CCNE2 & cyclin E2 splice variant I \\
\hline 202842_s_at & 4189 & 0.50 & $\begin{array}{l}\text { DKFZp564FI8 } \\
62\end{array}$ & hypothetical protein \\
\hline 222175_s_at & 51586 & 0.50 & FLJ00003 & FLJ00003 protein \\
\hline 20I500_s_at & 6992 & 0.50 & PPPIRI I & PPPIRII \\
\hline 203045_at & $48 \mid 4$ & 0.50 & NINJI & ninjurin I \\
\hline 206307_s_at & 2297 & 0.50 & FOXDI & forkhead box DI \\
\hline 216594_x_at & 1645 & 0.50 & chlordecone & chlordecone reductase homolog \\
\hline 220058_at & 79018 & 0.50 & MGC3048 & hypothetical protein MGC3048 \\
\hline 221213_s_at & 54816 & 0.50 & FLJ20086 & hypothetical protein FLJ20086 \\
\hline 218145_at & 57761 & 0.50 & LOC5776 I & $\begin{array}{l}\text { protein kinase domains containing proteinsimilar to } \\
\text { phosphoprotein C8FW }\end{array}$ \\
\hline 21940I_at & 64132 & 0.50 & XT2 & xylosyltransferase II \\
\hline 220587_s_at & 64223 & 0.50 & GBL & G protein beta subunit-like \\
\hline 214782 at & 11016626 & 0.47 & FLJI327 I & cDNA FLJI327I fis \\
\hline 214814_at & II 684382 & 0.47 & $\begin{array}{l}\text { DKFZp564P05 } \\
6\end{array}$ & cDNA DKFZp564P056 \\
\hline 21865I_s_at & 55323 & 0.47 & FLJIIII96 & hypothetical protein FLJIII96 \\
\hline 219039_at & 54910 & 0.47 & FLJ20369 & hypothetical protein FLJ20369 \\
\hline 221836_s_at & 6697854 & 0.47 & FLJ2274 I & Homo sapiens cDNA: FLJ2274 I fis \\
\hline 20343I_s_at & 9743 & 0.47 & KIAA07 I 2 & KIAA07I 2 gene product \\
\hline 203504_s_at & 19 & 0.47 & ABCAI & ATP-binding cassette, sub-family $A$, member I \\
\hline 209947_at & 9898 & 0.47 & KIAAOI 44 & KIAA0I44 gene product \\
\hline 21875I_s_at & 55294 & 0.44 & FLJ I I 07 I & hypothetical protein FLJI I07I \\
\hline 215078_at & 4914612 & 0.44 & $\begin{array}{l}\text { DKFZp564M2 } \\
422\end{array}$ & cDNA DKFZp564M2422 \\
\hline 204623_at & 7033 & 0.44 & TFF3 & Homo sapiens trefoil factor 3 (intestinal) \\
\hline 209182_s_at & 11067 & 0.44 & DEPP & decidual protein induced by progesterone \\
\hline 215670_s_at & 10434472 & 0.41 & FLJ 12782 & cDNA FLJI2782 fis \\
\hline 218920_at & 54540 & 0.41 & FLJ 10404 & Homo sapiens hypothetical protein \\
\hline 219747_at & 79625 & 0.41 & FLJ23 I 9 I & Homo sapiens hypothetical protein FLJ23 I9I \\
\hline 204469_at & 5803 & 0.41 & PTPRZI & $\begin{array}{l}\text { protein tyrosine phosphatase, receptor-type, } Z \text { polypeptide } \\
\text { I }\end{array}$ \\
\hline 2|253|_at & 3934 & 0.41 & LCN2 & Homo sapiens lipocalin 2 (oncogene 24p3) \\
\hline 211030_s_at & 13623302 & 0.38 & MGC: 10619 & clone MGC: 10619 \\
\hline 221959_at & 10032854 & 0.38 & FLJ22488 & FLJ22488 fis \\
\hline 209160_at & 8644 & 0.38 & c-hluPGFS & Homo sapiens mRNA for hluPGFS \\
\hline 212839_s_at & 6738 & 0.38 & SSA2 & $\begin{array}{l}\text { Sjogren syndrome antigen A2 (60 kD, ribonucleoprotein } \\
\text { autoantigen SS-ARo) }\end{array}$ \\
\hline 218864_at & 7145 & 0.35 & PRO0929 & PRO0929 mRNA \\
\hline 220123_at & 80255 & 0.35 & FLJ22004 & hypothetical protein FLJ22004 \\
\hline 207992_s_at & 272 & 0.35 & AMPD3 & adenosine monophosphate deaminase (isoform E) \\
\hline 213158_at & 1523376 & 0.33 & $\begin{array}{l}\text { DKFZp586B2I } \\
\text { I }\end{array}$ & cDNA DKFZp586B2II \\
\hline 213445_at & 23144 & 0.33 & KIAAOI50 & KIAA0I50 protein \\
\hline 219797_at & 11320 & 0.33 & MGAT4A & mannosyl-glycoprotein beta-acetylglucosaminyltransferase \\
\hline 219935_at & 11096 & 0.31 & ADAMTS5 & $\begin{array}{l}\text { disintegrin-like and metalloprotease with thrombospondin } \\
\text { type I motif }\end{array}$ \\
\hline 213156_at & 12761337 & 0.29 & $\begin{array}{l}\text { DKFZp586B2I } \\
\text { I }\end{array}$ & cDNA DKFZp586B2II \\
\hline 216006_at & 24694 & 0.27 & 24694 & clone 24694 \\
\hline 206273_at & 10650 & 0.27 & HFL-EDDG I & erythroid differentiation and denucleation factor I \\
\hline 218790_s_at & 55217 & 0.19 & FLJ 10727 & hypothetical protein FLJI 0727 \\
\hline 211037_s_at & 13623420 & 0.07 & MGC: 13 I 24 & clone MGC: 13124 \\
\hline 210709_at & 7770220 & 0.06 & PRO27IO & PRO27I0 mRNA \\
\hline 209613_s_at & 125 & 0.02 & ADH2 & alcohol dehydrogenase beta-I subunit \\
\hline 217177_s_at & 5262528 & 0.01 & FLJ 13658 & cDNA DKFZp564N2216 \\
\hline
\end{tabular}


A.

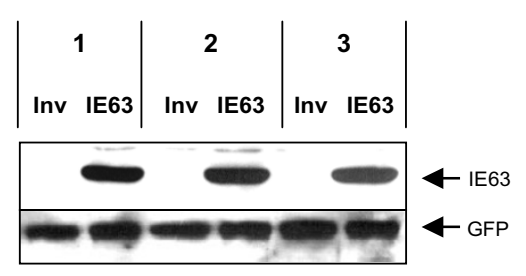

B.
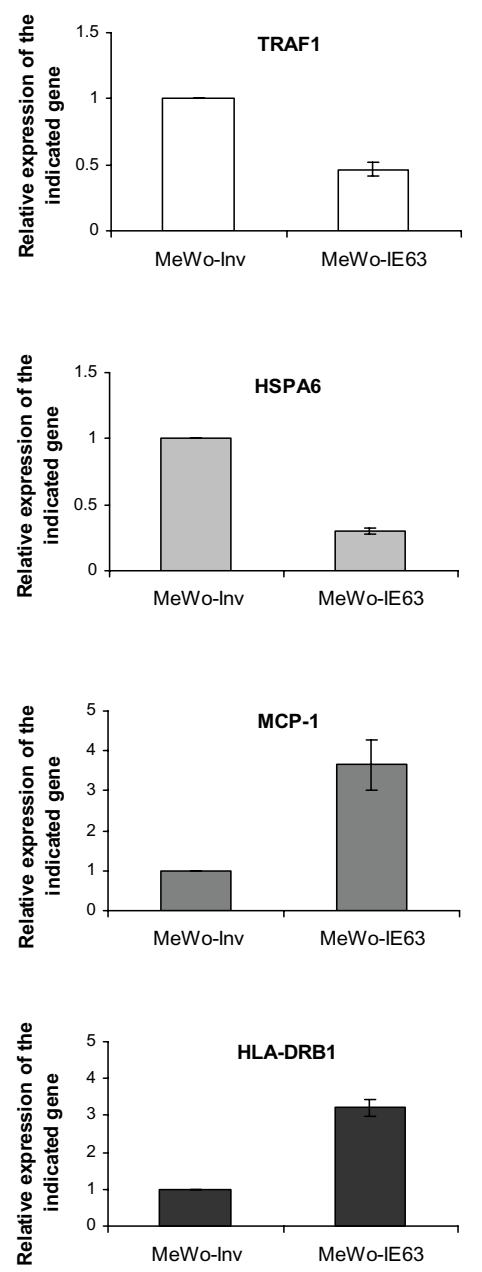

Figure 4

Relative expression of selected cellular genes in MeWoIE63 cells versus control cells. (A) Cells were lysed in radioimmunoprecipitation assay buffer and used for immunoblotting with mouse monoclonal antibody to the ORF63 protein or with rabbit polyclonal antibody to the GFP. (B) mRNA levels (TRAFI, HSPA6, MCP-I, and HLA-DRBI) were determined by quantitative real-time PCR and normalized using the $\beta 2$-microglobuline transcripts. Experiments were done at least in triplicate. Differences ( $\mathrm{n}$-fold) between samples were calculated using the standard-curve method and the 2- $\mathrm{ACt}$ method. $\rho$-values were calculated using the graphpad quickcalcs software [59]: *, significantly different from control (Inv ; p-value < 0.05).
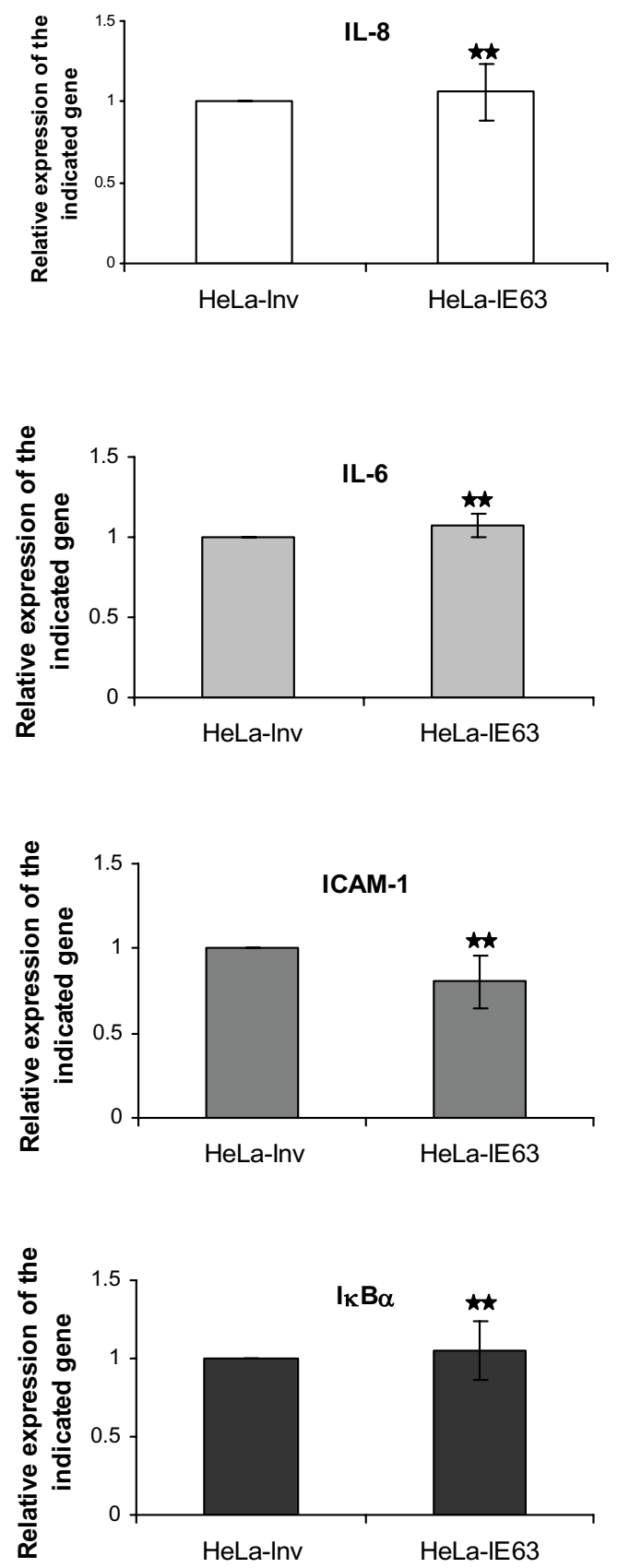

Figure 5

Relative basal expression of IL-8, IL-6, ICAM-I and IKB $\alpha$ genes in HeLa-IE63 cells compared to control cells. mRNA levels (IL-8, IL-6, ICAM-I, and IKB $\alpha$ ) were determined by quantitative real-time PCR in unstimulated HeLa cells expressing or not IE63 and normalized using the $\beta 2$ microglobuline transcripts. Experiments were done at least in triplicate. Differences ( $n$-fold) between samples were calculated using the standard-curve method and the $2-\Delta \mathrm{Ct}$ method. $\rho$-values were calculated using the graphpad quickcalcs software [59] : **, not significantly different from control (Inv; p-value $\geq 0.05$ ). 

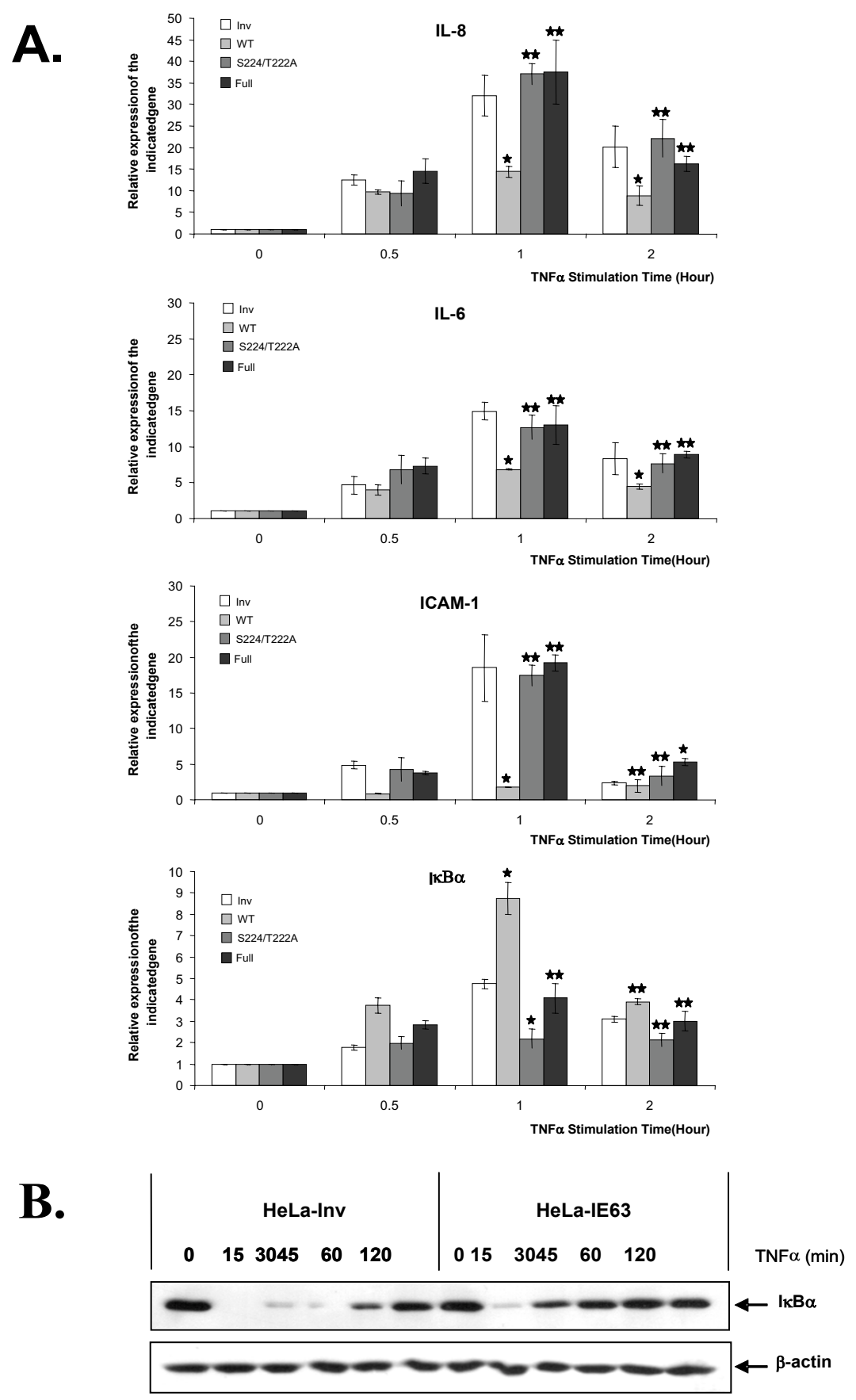

\section{Figure 6}

Relative expression of IL-8, IL-6, ICAM-I and IKB $\alpha$ genes in HeLa cells expressing IE63, IE63-S224/T222A, and IE63Full versus control cells stimulated or not with TNF $\alpha$. HeLa cells expressing IE63 wild-type, IE63-S224/T222A, IE63-Full or IE63 in inverted orientation (Inv, control) were treated for increasing times (from 0 to $2 \mathrm{~h}$ ) with TNF $\alpha$ at a final concentration of $200 \mathrm{U} / \mathrm{mL}$. (A) Total RNA extracts were isolated and analyzed by Real-time RT-PCR using primers for the IL-8 mRNA, IL-6

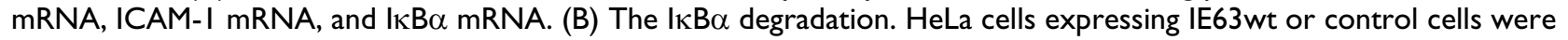
treated for increasing times (from 0 to $2 \mathrm{~h}$ ) with TNF $\alpha(200 \mathrm{U} / \mathrm{mL})$. I $\mathrm{kB} \alpha$ degradation was followed by Western Blotting on total cellular extracts. $\beta$-actin Western Blotting detection was used as loading control (lower panel). $\rho$-values were calculated using the graphpad quickcalcs software [59]: *, significantly different from control (Inv; p-value $<0.05)$; **, not significantly different from control (Inv; p-value $\geq 0.05$ ). 
tion. For this, we compared IL-8, IL-6, ICAM-1, and IкB $\alpha$ RNA levels in HeLa cells expressing either IE63, or the two mutated forms (IE63-S224/T222A, and IE63-Full). As it shown in Fig. 6A, when phosphorylation is suppressed by alanine substitution, IE63 did not significantly modulate the TNF $\alpha$-induced gene transcription, demonstrating the importance of correct phosphorylation of IE63 for this property.

\section{IE63 perturbs chromatin structure and NF- $\kappa B$ binding on} the TNF $\alpha$ modulated gene promoters

To go one step further in the understanding of the mechanism by which IE63 modified IL- 8 , ICAM-1, and I $\mathrm{B} \alpha$ inducibility by $\mathrm{TNF} \alpha$, chromatin immuno-precipitation assays (ChIP) were carried out. Histone acetylation and histone deacetylase (HDAC) removal were often associated with an increased chromatin accessibility at NF-кB- responsive promoters [29]. Using an antibody directed against the acetylated lysine 9 of histone H3 in ChIP assay, it was obvious that IE63 expression led to opposite effects: it reduced IL-8 and ICAM-1 promoters accessibility whereas it increased $\mathrm{I} \kappa \mathrm{B} \alpha$ promoter accessibility upon TNF $\alpha$ (Fig.7A). The decreased accessibility of the IL- 8 and ICAM-1 promoters mediated by IE63 correlated very well with a recruitment of HDAC3 while the reverse was

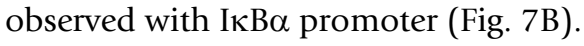

Since results from our laboratory (El Mjiyad et al., submitted) showed that VZV is able to interfere with the immune response by inhibiting NF- $\kappa \mathrm{B}$ binding to specific promoters, we investigated the in vivo recruitment of the NF- $\kappa \mathrm{B}$ subunit p65 on IL-8, ICAM-1, and I $\kappa$ B $\alpha$ promoters. HeLaIE63 and control cells (HeLa-Inv) were treated during increasing times (from 0 to $2 \mathrm{~h}$ ) with TNFa $(200 \mathrm{U} / \mathrm{mL})$.

\section{A.B. H3K9p65 HDAC3 C.}
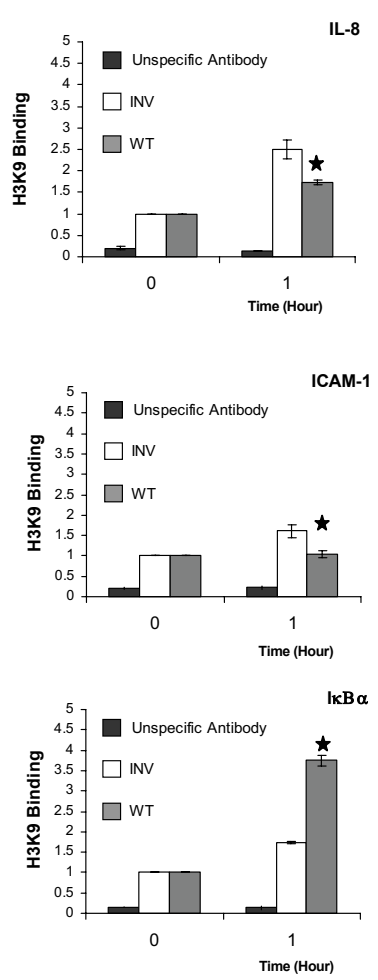
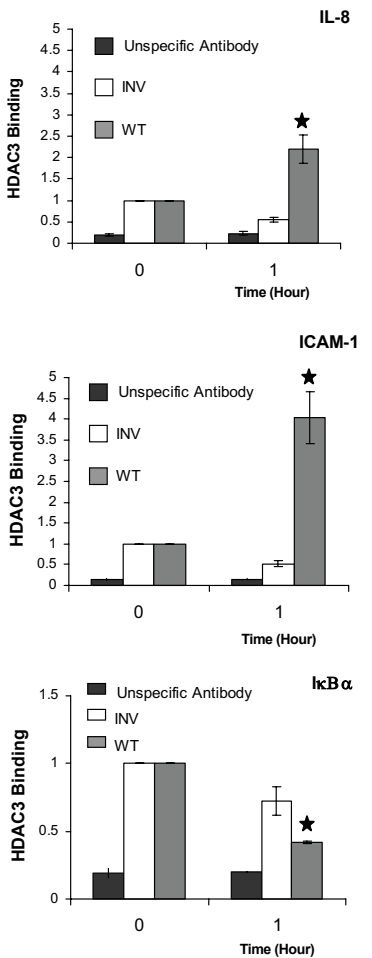
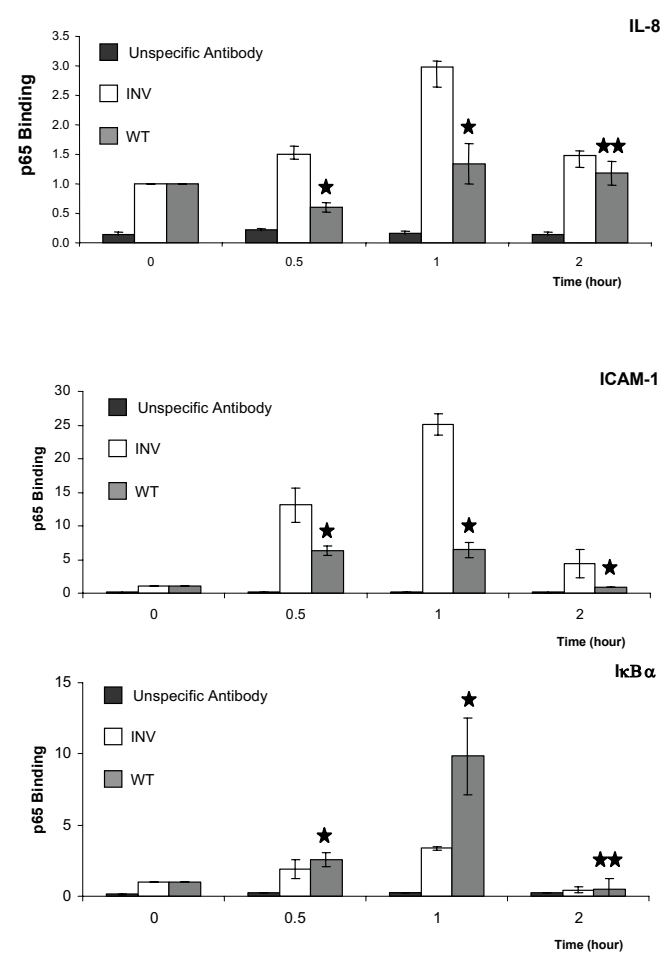

\section{Figure 7}

HDAC3, NF- $\kappa B$ recruitment, and Histone $H 3$ acetylation on selected cellular genes in HeLa cells expressing IE63 versus control cells. (A, and B) HeLa cells were treated for one hour with TNF $\alpha(200 \mathrm{U} / \mathrm{mL})$ and ChIP assay analysis was performed using an antibody specific of the K9 acetylated form of the histone H3 (A) and the histone deacetylase HDAC3 (B). An unspecific antibody (Flag) was used for evaluating specificity. (C) HeLa cells were treated for increasing times (from 0 to 2 h) with TNF $\alpha$ at a final concentration of $200 \mathrm{U} / \mathrm{mL}$. ChIP assay using $\mathrm{p} 65$ antibodies was performed on total cell lysates. Real-time PCR amplification of a 100 bp fragment from the IL-8, ICAM-I and I $\mathrm{B} \alpha$ promoter encompassing the proximal NF- $\kappa B$ site was carried out. $\rho$-values were calculated using the graphpad quickcalcs software [59] : *, significantly different from control (Inv ; $p$ value $<0.05)$; **, not significantly different from control (Inv ; $p$-value $\geq 0.05$ ). 
After chromatin immunoprecipitation using specific antibodies to p65, quantitative PCR amplification of a region of 100 bp surrounding the NF-kB site(s) on the IL-8, ICAM- 1 and IкB $\alpha$ promoters was carried out. As shown in Fig. 7C, the cells treatment during one hour with TNFa induced a 3- and 25-fold increase of p65 binding at the NF- $\mathrm{KB}$ proximal site of the IL-8, and ICAM-1 promoter, respectively. In HeLa-IE63 cells, this increase was significantly diminished. We then looked at I $\mathrm{I} B \alpha$ promoter, and it turned out that the presence of IE63 increased p 65 binding (Fig. 7C). Indeed, after one hour of TNF $\alpha$ treatment, a 3 -fold increase of p65 binding was observed in control cells, whereas in IE63 expressing HeLa cells, a 10-fold increase was observable, demonstrating again that IE63 enhanced p65 recruitment at the IкB $\alpha$ promoter.

\section{Discussion}

IE63 is of particular interest in Varicella Zoster Virus pathogenesis since it is abundantly expressed during acute as well as latent infection [15]. The activity of IE63 as a potential transcriptional regulator has been subject to controversy for years, being described either as an activator or a repressor of transcription [17,22-27].

To clarify this issue, the first part of this work was devoted to the examination of the effects of IE63 on cellular gene expression using a whole genome micro-array analysis in HeLa and MeWo cells stably expressing IE63. The main results obtained in this study can be summarized as follow: (i) IE63 alone affected on a cell-type mode the transcription of a limited number of human genes, including genes implicated in signal transduction, transcription, immunity, and heat-shock signalling. (ii) IE63 expression led to an inhibition or an increase of RNA POL II binding on the down- and up-regulated promoters tested here. (iii) In HeLa cells, the correct phosphorylation of the protein is a crucial event for its regulatory properties on endogenous promoters.

Expression of IE63 protein by a lentivirus influenced the transcription of relatively few cellular genes in HeLa (26 genes) and MeWo cells (106 genes). Previous micro-array studies performed with VZV-infected cells indicated that VZV was able to modify the expression of a variable number of genes depending on the cell type used [30,31]. Comparative micro-array analysis of IE63 expressing cells demonstrated many differences in depending on the cell type considered. Indeed, Hoover et al. [28] showed that, in human diploid fibroblasts (MRC-5), 71 genes of approximately 33,000 genes were up-regulated and 23 were down-regulated by IE63 protein. In human neuroblastoma (SKNSH), no significant differences in the expression level of cellular genes was found between control and IE63 expressing cells [28].
Several explanations might be proposed to explain these differences in response to IE63. First, as we and other have already shown, IE63 is a heavily phosphorylated protein and the phosphorylation pattern is cell-type dependent $[17,24,25,32]$. Another reason may be found in the chromatin context and promoter accessibility that may be different in the two cell types investigated. In the various works cited above, IE63 was expressed in several cellular backgrounds whose gene expression is likely to be differently affected by growth in cell culture. A last explanation is the viral vector used. Hoover $e t$ al. measured the effect of IE63 as soon as two days after cell infection with an adenovirus [28] whereas lentivirus was used in our work. It could be conceivable that infection mediated by adenovirus increased by itself chromatin accessibility allowing IE63 to access to a greater number of promoters, and then having a higher influence on cellular genes expression.

It must also be pointed out that the comparison between IE63 expression in MRC5 [28] and MeWo cells exhibited several common features. Histone $\mathrm{H} 2$ coding genes were up-regulated in both cell types while Heat Shock Protein 70 (hsp70) and TNFa-induced protein (TNFAIP) genes were down-regulated. While several viruses (including Herpesvirus and Adenovirus) have been reported to induce hsp70 genes [33-36], it is not clear yet why IE63 specifically and drastically down-regulated the members of this family.

Among the rather limited list of genes regulated in HeLa cells mediated by IE63, the down-regulation of the gene encoding the component protein 3 could be noticed. The complement system comprises several dozen proteins circulating in serum, or attached to cell surfaces, and orchestrating three distinct cascades (classical, alternative, and lectin pathways) into antimicrobial effector activities that range from the opsonization of foreign particles, the recruitment of phagocytes, to the lysis of infected cells [37]. The complement cascade is under tight cellular control by host inhibitor proteins, and it is perhaps not surprising that VZV has an inhibitory effect as an anticomplement defence system. Some viruses, for example HCMV, induce the expression of cellular complement inhibitors like DAF at the surface of infected cells [38]. The Epstein-Barr virus (EBV) also has complement regulatory activity against C3 [39]. Different studies have shown that HSV-1 and -2 gC proteins offer protection against viral neutralization mediated by complement $[40,41]$.

When gene expression profiles obtained in this paper are compared to micro-array data obtained by the analysis of VZV infected cells $[30,31]$, there are several global similarities that showed up, and among them, genes implicated in immunity/inflammation, signal transduction, and transcription in T cells, or in fibroblasts, as well as in VZV- 
infected skin xenografts. These classes of genes are also influenced when IE63 is expressed alone. For instance, among genes implicated in immunity/inflammation, TRAF (TNF Receptor-Associated Factor) genes are downregulated in VZV-infected T cells as well as in IE63 expressing MeWo cells. Concerning signal transduction, two Ras oncogene family members and genes coding for $\mathrm{G}$ protein receptors were also down-regulated in both cases. Our work demonstrated that MCP-1 gene expression was stimulated by IE63, and this result is in accordance with what was shown by Jones et al. in VZV-infected cells [31].

Another important finding of this work was the demonstration that IE63 can differentially affect the TNF-inducibility of NF-KB regulated genes. The relevant results obtained here are: (i) in TNF $\alpha$-stimulated cells, the expression of IL-8, IL-6, ICAM-1, and IкB $\alpha$ genes was affected by IE63 in a promoter-dependent manner, (ii) the phosphorylation status of the protein influenced these regulatory properties, (iii) the effects of IE63 were correlated with a modification of chromatin structure, and finally (iv) IE63 was able to modulate NF- $\mathrm{BB}$ binding on the tested promoters.

We have been able to show that TNF $\alpha$ treatment increases chromatin accessibility in the proximal area of the tested promoters as demonstrated by histone $\mathrm{H} 3$ acetylation and the inhibition of HDAC3 binding. Furthermore, the presence of IE63 modified chromatin in a different extent depending on the considered promoter. Unexpectedly, IE63 led to inhibition of chromatin accessibility mediated by TNF $\alpha$ on IL- 8 and ICAM- 1 genes, and to an increased accessibility in the context of the IкB $\alpha$ promoter. The inhibition of IL-8, and ICAM-1 gene expression could very well be a consequence of the induction of I $\mathrm{B} \alpha$, since this protein is an inhibitor of NF- $\mathrm{KB}[42,43]$.

NF- $\mathrm{BB}$ plays a central role in the innate and adaptive immune response. The activation of this factor during early stages of viral infection leads to the expression of several immune response genes; such as pro-inflammatory cytokines (IFN- $\beta$, TNF- $\alpha$, IL- 6 , IL-8), chemokines (RANTES) and adhesion molecules (ICAM-1, VCAM-1). NF-KB also strongly induces MHC-I and CD80/86 expression on antigen presenting cells, thus increasing T-cell activation [44]. NF- $\mathrm{KB}$ activation appears to be necessary for optimal replication of HSV- 1 and HCMV early in infection, since it has been shown that blocking the NF-кB pathway decreased viral yields and inhibited the activation of several viral genes harbouring NF- $\mathrm{BB}$ response elements in their promoter [45,46]. A model of this interdependence between HCMV and NF-кB has been generated by Montag et al. [47]. In contrast, the lack of functional NF- $\kappa B$ response elements in the promoters of VZV IE genes allows suspecting that VZV replication cycle could be NF-אB independent. VZV may need to directly interfere with the NF- $\kappa B$ signalling in order to avoid downstream effects of NF- $\kappa B$ activation. Likely, NF- $\kappa B$ inhibition properties of VZV could at least in part be mediated by IE63. Such a modulation mechanism of NF$\kappa B$ has already been demonstrated with HCMV. Indeed, Taylor et al. have shown that HCMV Immediate Early protein IE86 can suppress virus-induced pro-inflammatory cytokines transcripts expression by efficiently blocking the binding of NF- $\kappa B$ to cellular NF- $\kappa B$ responding genes [48]. Surprisingly it has been shown that VZV specifically induced interleukin- 6 in human monocytes via TLR2dependent activation of NF- $\mathrm{KB}$ [49]. Moreover Rahaus et al. have demonstrated that infection by VZV caused a significant increase in activation of JNK/SAPK in the early phase of infection and an increase in activation of p38/ MAPK in the later phase. Subsequent cascades to induce pro-inflammatory responses were activated whereas cascades to activate apoptotic events were not [50]. This suggests that activation of stress pathways by VZV infection represents a finely regulated system that activates cellular transcription factors for transregulation of VZV-encoded genes, but prevents activation of cellular defence mechanisms [50].

The observation that I $\mathrm{I} \mathrm{B} \alpha$ transcription was stimulated when IE63 expressing cells were treated with TNFa suggests that the strategy by which VZV, may be via IE63, inhibits the NF- $\kappa \mathrm{B}$ pathway may protect VZV-infected cells from antiviral responses induced by exogenous proinflammatory cytokines, many of which act through NF$\kappa \mathrm{B}$ signalling pathways.

One of the main information brought by this work is the capacity of the IE63 to exert epigenetic effects on NF- $\kappa B$ regulated promoters. Similar effects on chromatin have been observed with other $\alpha$-Herpsvirus. Indeed, in HSV-1 infected cells, ICP0, the homologue of VZV ORF61 protein, has been shown to block viral genes silencing by interacting with HDAC1 [51]. Moreover, the $\mathrm{U}_{\mathrm{s}} 3$ kinase (the VZV ORF66 kinase homolog) can also block this silencing in a mechanism distinct from that of ICP0 $[52,53]$. It has been demonstrated that during lytic infection HSV-1 is associated with histone bearing modifications that correlate with active transcription [51], ICP0 may be responsible for this chromatin permissiveness. Concerning the Bovine Herpesvirus 1 (BHV-1), it has been shown that bICP0 can associate with HDAC1 to relieve HDAC1-mediated repression of viral gene transcription [54]. Furthermore, this protein was able to interact with p300/CBP (CREB Binding Protein) and this interaction cooperate to enhance viral gene expression and may interfere with antiviral signalling [55]. 


\section{Conclusion}

In conclusion, this work clearly demonstrated that stable expression of IE63 in two cellular backgrounds only affected the basal expression of a rather limited number of genes while it differentially modulated the TNF $\alpha$-inducibility of several NF-kB-regulated genes. While the molecular mechanisms governing these effects are not established yet, it can be suspected that IE63 is a major player in the complex interplay between VZV and the host immune system.

\section{Methods}

\section{Cells lines}

MeWo cells, a continuous human melanoma cell line (ECACC93082609), were grown in EMEM (Biowhittaker) supplemented with $10 \%$ foetal bovine serum (FBS, biowhittaker), 1\% L-glutamine, and 1\% non-essential amino acids (NEAA, GibcoBRL).

HeLa cells, human epithelial cells from a fatal cervical carcinoma transformed by human papillomavirus 18 (ATCC-CCL-2), were cultivated in Eagle's Modified Essential Medium (EMEM, Biowhittaker) supplemented with $10 \%$ foetal calf serum (FCS, Biowhittaker), and 1\% Lglutamine.

293FT cells, derived from 293 cell line established from primary embryonic human kidney transformed with sheared human adenovirus type 5 DNA, were grown in Dulbecco's Modified Eagle's Medium (DMEM, Biowhittaker) supplemented with $10 \%$ FBS, 1\% L-glutamine, $1 \%$ NEAA, and $1 \%$ Penicillin/Streptavidine (P/S).

Lentiviruses in which the ORF63 has been cloned in the sense (Lenti-IE63), or in the anti-sense orientation (LentiInv, control) were produced by transient calcium phosphate co-transfection of 293FT cells with the plasmid carrying the IE63 gene (pTRIP-EFI $\alpha$-ORF63-IRES-EGFP [56]), pCMV8.91 (a kind gift from Dr. D. Trono [57]) and pVSV-G (a kind gift from Dr. T. Friedmann [58]) as previously described [56]. A similar procedure was followed to generate a lentivirus in which the ORF63 was mutated either at S224/T222A (Lenti-IE63-S224/T222A), or on all the target residues of CK1, CK2, and CDK1, i.e. S15A, S150A, S157A, S165A, T171A, S173A, S181A, S185A, S186A, S197A, S200A, T201A, S203A, T222A, S224A, and T224A (Lenti-IE63-Full) [24]. All of these constructs contain the gene encoding the enhanced green fluorescent protein (EGFP). Lentivirus concentrations were determined by measuring the HIV-1 p24 capsid protein. The viral titers were measured on the CEMx174 cells and expressed in TU/mL (Transduction Unit/mL).

HeLa and MeWo cells were plated at $5 \times 10^{5}$ cells $/ \mathrm{mL}$ and the lentiviral particles were added at the concentration of
$500 \mathrm{ng} / \mathrm{mL}$ of viral $\mathrm{p} 24$. After $12 \mathrm{~h}$, cells were washed and cultured for $72 \mathrm{~h}$. EGFP expression was confirmed by flow cytometry analysis. This procedure allowed us to generate four HeLa cell lines, i.e. HeLa-IE63, HeLa control cells (HeLa-Inv), HeLa-IE63-S224/T222A, and HeLa-IE63-Full, and two MeWo cell lines, MeWo-IE63, and control cells (MeWo-Inv).

\section{Antibodies and reagents}

$\mathrm{TNF} \alpha$ was purchased from Roche and used at a final concentration of $200 \mathrm{U} / \mathrm{mL}$. The antibodies used in this work (Western blot analysis and immunofluorescence) are directed against IE63 (produced by Dr. S. Bontems, University of Liège, Belgium), Green Fluorescent Protein (GFP) (Rabbit polyclonal, 1/1000 ; Tebu Bio SC-8334), p65 (Rabbit polyclonal, 1/1000 ; Tebu Bio SC-372), IкB $\alpha$ (Mouse monoclonal, 1/400 ; kind gift from Ron Hay, Scotland), $\beta$-Actin (Mouse monoclonal, 1/1000 ; Sigma), H3AcK9 (Mouse monoclonal, 1/1000 ; Upstate Cell Signaling), HDAC3 (Mouse monoclonal, 1/1000 ; Upstate Cell Signaling), Histone H3 (Mouse monoclonal, 1/500 ; Abcam), and Human RNA polymerase II (Rabbit polyclonal, 1/200 ; Tebu Bio).

\section{Immunofluorescence}

HeLa and MeWo control cells or expressing wild-type or mutated IE63 were seeded on coverslides into $10-\mathrm{mm}$ dishes and grown in EMEM (Biowhittaker) supplemented with 10\% FBS (Biowhittaker) and 1\% L-glutamine. Fortyeight hours post-seeding, the cells were fixed with $4 \%$ (w/ v) paraformaldehyde/PBS for $10 \mathrm{~min}$ at room temperature and $20 \mathrm{~min}$ at $37^{\circ} \mathrm{C}$. After washing with PBS, cells were permeabilized with PBS containing $0.1 \%$ Triton X100 for $10 \mathrm{~min}$ at room temperature and $20 \mathrm{~min}$ at $37^{\circ} \mathrm{C}$. Cells were then incubated with monoclonal mouse anti63 antibody in PBS $+1 \%$ fetal bovine serum (FBS) for $1 \mathrm{~h}$ at $37^{\circ} \mathrm{C}$. After washing with PBS and FBS $(1 \%)$, coverslides were incubated with a Texas Red-conjugated antimouse secondary antibody (1/1000; Molecular Probes) for $1 \mathrm{~h}$ at $37^{\circ} \mathrm{C}$. Following a water wash, cells were observed by fluorescent microscopy (Nikon).

\section{Western Blot analysis}

HeLa or MeWo cells expressing or not wild-type or mutated IE63 were lysed in radioimmunoprecipitation assay buffer $(10 \mathrm{mM}$ Tris-HCl pH 8, $100 \mathrm{mM} \mathrm{NaCl}, 1 \mathrm{mM}$ EDTA, $1 \%$ NP-40, 0.5\% SDS) containing complete protease inhibitor cocktail (Roche), and $5 \mu \mathrm{g}$ of proteins were separated on a $10 \%$ SDS-polyacrylamide gel. Proteins were transferred to nitrocellulose and detected with a mouse monoclonal anti-63 antibody. Western Blot analysis of IкB $\alpha$ degradation was done using a mouse monoclonal antibody directed against IкB $\alpha$ (kind gift from Ron Hay, Scotland) and a secondary horseradish peroxidaseconjugated rabbit anti-mouse antibody (Dako A/S). West- 
ern Blot using antibody directed against $\beta$-actin was used as loading control.

\section{Regulatory properties test}

Transient transfection studies were carried out with HeLa cells (HeLa-IE63 and HeLa-Inv) seeded into 35-mm diameter 6-well cluster dishes using the FuGENE6 transfectant reagent (Roche). The plasmid pPol-luc, where the Firefly luciferase gene is under the control of the VZV DNA polymerase gene promoter [25], was used as reporter vector. The same quantity of each plasmid was transfected in each experiment. Twenty-four hours post-transfection, luciferase assays were performed using "Luciferase Reporter Gene Assay, High Sensitivity" kit (Roche) according to the manufacturer's instructions. For each experiment, the concentration of proteins was measured to normalize the results. Data from luciferase assays were collected from six independent transfection experiments. $\rho$-values were calculated using the graphpad quickcalcs software [59].

\section{Human gene micro-array analysis}

Cells expressing or not wild-type or mutated IE63 were cultivated as described above then harvested and stored in RNA Later (Qiagen) at $-70^{\circ} \mathrm{C}$. Three independent experiments were performed, and the cell pellets were all processed in parallel. Total RNA was extracted from the cell pellets using the Rneasy mini kit (Qiagen). Synthesis of double-stranded DNA, in vitro transcription of biotinlabelled RNA, and fragmentation of labelled RNA were performed using the Genechip One-Cycle Target Labeling and Reagents kit (Affymetrix). The cRNA were then hybridized to U133A GeneChips (Affymetrix). The data generated from the three independent experiments were analyzed using the MSCL Analyst's Toolbox [60]. Affymetrix MAS5.0 signal values were retrieved, and a SSG transformation was applied. Only the significant differences based on $\rho$-values retrieved from three independent experiments were considered further. Comparisons were done using a one-way analysis of variance with transformed normalized data.

\section{Real-time PCR}

Real-time PCR amplification was performed using $10 \mathrm{ng}$ of each purified cDNA. The primers used were designed using the software Primers Express ${ }^{\mathrm{TM}}$ and were obtained from Eurogentec (Table 3).

PCRs were run on an ABI 7700 instrument with the SYBR Green Master Mix (Applied Biosystems) and data were analyzed using Sequence Detector software (Applied Biosystems). Results were normalized using the $\beta 2$ microglobulin transcripts. Experiments were done at least in triplicate. Differences ( $\mathrm{n}$-fold) between samples were calculated using the standard-curve method and the $2-\Delta \mathrm{Ct}$ method [61]. $\rho$-values were calculated using the graphpad quickcalcs software [59].

\section{Chromatin Immuno-precipitation assay}

The ChIP assays were carried following the Upstate Cell Signalling protocol. In short, DNA was sonicated during twenty minutes (alternatively 30 s of sonication followed by 30 s of rest). The protein A Agarose beads (Pierce) were saturated with Herring Sperm DNA (Sigma-aldrich), $1 \mu \mathrm{g}$ DNA/20 $\mu \mathrm{L}$ protein A Agarose. All ChIP assays were performed at least three times. qPCR targeting the promoter

Table 3:

\begin{tabular}{|c|c|c|}
\hline Gene & Forward primer & Reverse primer \\
\hline $\mathbf{C} 3$ & 5'-gagccaccgaaaaatggaatc-3' & $5^{\prime}$-gatccctttcttgtccgacatg $-3^{\prime}$ \\
\hline GATA3 & 5 '-tgaagcctaaacgcgatggata-3' & 5'-ggtccagattcagtggttggaa-3' \\
\hline RCEI & 5'-tggagttgcccattttcacc-3' & 5'-aagcagtgtaggcaccgaagac- 3 ' \\
\hline RAB8B & 5'-cgccttcaacaccaccttcat-3' & $5^{\prime}$-cgctgtgtcccatatctgaagc- $3^{\prime}$ \\
\hline WIFI & 5'-tggcagatccaaccgtcaat-3' & $5^{\prime}$-tgccaccccatcctgtttt- $3^{\prime}$ \\
\hline CYFIP2 & 5'-tccgagaggccaatcacaat-3' & $5^{\prime}$-cgcacaaaacggttagtggac-3' \\
\hline NELL2 & 5'-gcccagatcttaatcgcacct-3' & 5'-gcttggctgatgttttggct-3' \\
\hline GPR37 & 5'-gtcatgtgtctgtccgtggtga-3' & 5'-ttggagatgctccgcatgtag-3' \\
\hline KCNJI 2 & 5'-tttctggtgtcgeccatca-3' & 5'-ccaggatgaccacgatctcaa-3' \\
\hline HSP70 & 5'-agcagacgcagatcttcacca-3' & $5^{\prime}$-aagcgccccaacagattgt-3' \\
\hline ICAMI & 5'-agaccttagcgcggtgtaga-3' & 5'-agtagcagaggagctcagcg-3' \\
\hline IL8 & 5'-gggccatcagttgcaaatc-3' & $5^{\prime}$-ttccttccggtggtttcttc- $3^{\prime}$ \\
\hline IL6 & 5 -aagcacactttccccttcc-3' & $5^{\prime}$-ctatcgttcttggtgggctc- $3^{\prime}$ \\
\hline $\mathbf{I} \kappa \mathbf{B} \alpha$ & 5'-ccaaccagccagaaattgct-3' & 5'-tctcggagctcaggatcaca-3' \\
\hline TRAFI & 5'-gctttttattgttcccacggct-3' & $5^{\prime}$-actcgctaggccagaccttcat-3' \\
\hline HSPA6 & $5^{\prime}$-ccattgacgctggtgtctttg-3' & $5^{\prime}$-cgccggaattcttccatga- $3^{\prime}$ \\
\hline MCPI & 5'-tctcgcctccagcatgaaagt-3' & 5'-gcattgattgcatctggctga-3' \\
\hline HLA-DRB I & 5'-cccagtactggaacagccagaa-3' & $5^{\prime}$-tgcactgtgaagctctcaccaa-3' \\
\hline$\beta 2$-microglobuline & $5^{\prime}$-gagtatgcctgccgtgtg-3' & 5'-aatccaaatgcggcatct-3' \\
\hline
\end{tabular}


region of each gene were performed on the immunoprecipitated DNA. The primers used were designed using the software Primers Express ${ }^{\mathrm{TM}}$ : ICAM-1-FW (5'-cccgattgctttagcttggaa-3') and ICAM-1-RV (5'-ccggaacaaatgctgcagttat3'), IL-8-FW (5'-gccatcagttgcaaatcgtg-3') and IL-8-RV (5'agtgctccggtggctttt-3'); IкB $\alpha$-FW (5'-cgctcatcaaaaagttccctg$\left.3^{\prime}\right)$ and IкB $\alpha-R V$ (5'-ggaatttccaagccagtcagac-3'). For unspecific binding to the beads, treated cells extracts were incubated with $2 \mu \mathrm{g}$ of unspecific antibody (Flag, Sigmaaldrich). The following antibodies were used: p65, H3AcK9, HDAC3, Histone H3, and Human RNA polymerase II. Data were analysed using AbiPrism 7000 Sequence Detection System Software. Ct values obtained were normalized following Livak et al. [61]. $\rho$-values were calculated using the graphpad quickcalcs software [59].

\section{List of abbreviations}

VZV, Varicella-Zoster Virus ; CDK1, Cyclin-Dependent Kinase 1 ; IE, Immediate Early ; E, Early ; L, Late ; IE63, Immediate Early 63 protein ; ORF, Open Reading Frame ; HSV, Herpes Simplex Virus ; NFאB, Nuclear Factor $\kappa B$; IL6/8, Interleukin 6/8 ; ICAM-1, Intercellular Adhesion Molecule-1 ; TNF $\alpha$, Tumor Necrosis Factor $\alpha$; ChIP assay, Chromatin Immunoprecipitation assay ; HDAC, Histone Deacetylase.

\section{Authors' contributions}

LH constructed the cell lines expressing IE63, carried out the micro-arrays analysis, western-blotting analysis and regulatory properties of IE63. NEM set-up the ChIP analysis. EDV constructed the pTRI-EF1a-ORF63-IRES-EGFP vectors. CSD involved in drafting the manuscript and revising it critically for important intellectual content. SB obtained several mutated forms of IE63. JP contributed to the conception and design of the experiments, involved in drafting the manuscript and revising it critically for important intellectual content; and gave the final approval of the version to be published.

\section{Acknowledgements}

This work was supported by a research grant from the Belgian National Fund for Scientific Research (FNRS, Brussels, Belgium). LH is PhD student supported by the FRIA (Brussels, Belgium), N E-M is teacher assistant at the University of Liege, ED and SB are post-doctoral fellows, C S-D is Senior Research Associate at the University of Liège and JP is Research Director from the FNRS. We thank Dr. R. Hay (Scotland) for the kind gift of the $1 \kappa B \alpha$ antibody, Dr. T. Friedman (La Jolla, California, USA) for the plasmid pVSVG, Dr. D. Trono (C.M.U, Geneve, Switzerland) for the plasmid pCMV8.9I, and Emmanuel Ravet for his advice in the generation of stable cell lines.

\section{References}

I. Flisser A, Tapia-Conyer R: Epidemiology of varicella infections. Contrib Microbiol 1999, 3:76-85.

2. Croen KD, Ostrove JM, Dragovic LJ, Straus SE: Patterns of gene expression and sites of latency in human nerve ganglia are different for varicella-zoster and herpes simplex viruses. Proc Natl Acad Sci U S A 1988, 85(24):9773-9777.
3. Kennedy PG, Grinfeld E, Bell JE: Varicella-zoster virus gene expression in latently infected and explanted human ganglia. JVirol 2000, 74(24): I I893-II898.

4. Cohrs RJ, Barbour M, Gilden DH: Varicella-zoster virus (VZV) transcription during latency in human ganglia: detection of transcripts mapping to genes $21,29,62$, and 63 in a cDNA library enriched for VZV RNA. J Virol 1996, 70(5):2789-2796.

5. Baiker A, Bagowski C, Ito H, Sommer M, Zerboni L, Fabel K, Hay J, Ruyechan W, Arvin AM: The immediate-early 63 protein of Varicella-Zoster virus: analysis of functional domains required for replication in vitro and for T-cell and skin tropism in the SCIDhu model in vivo. J Virol 2004, 78(3): I 18I-1194.

6. Hay J, Ruyechan W: varicella zoster virus-a different kind of herpesvirus latency? seminars in virology 1994, 5:24I-247.

7. Everett RD: The regulation of transcription of viral and cellular genes by herpesvirus immediate-early gene products (review). Anticancer Res 1987, 7(4A):589-604.

8. Lungu O, Panagiotidis CA, Annunziato PW, Gershon AA, Silverstein S): Aberrant intracellular localization of Varicella-Zoster virus regulatory proteins during latency. Proc Natl Acad Sci U S A 1998, 95( I 2):7080-7085.

9. Debrus S, Sadzot-Delvaux C, Nikkels AF, Piette J, Rentier B: Varicella-zoster virus gene 63 encodes an immediate-early protein that is abundantly expressed during latency. J Virol 1995, 69(5):3240-3245.

10. Mahalingam R, Wellish M, Cohrs R, Debrus S, Piette J, Rentier B, Gilden DH: Expression of protein encoded by varicella-zoster virus open reading frame $\mathbf{6 3}$ in latently infected human ganglionic neurons. Proc Natl Acad Sci U S A 1996, 93(5):2 I 22-2 24.

II. Kennedy PG, Grinfeld E, Bontems S, Sadzot-Delvaux C: VaricellaZoster virus gene expression in latently infected rat dorsal root ganglia. Virology 200I, 289(2):2I8-223.

12. Sato H, Pesnicak L, Cohen Jl: Varicella-zoster virus ORF47 protein kinase, which is required for replication in human $T$ cells, and ORF66 protein kinase, which is expressed during latency, are dispensable for establishment of latency. J Virol 2003, 77(20): I I I80-I I I85.

13. Gary L, Gilden DH, Cohrs RJ: Epigenetic regulation of varicellazoster virus open reading frames 62 and 63 in latently infected human trigeminal Ganglia. J Virol 2006, 80(10):492I-4926.

14. Mitchell BM, Bloom DC, Cohrs RJ, Gilden DH, Kennedy PG: Herpes simplex virus- $I$ and varicella-zoster virus latency in ganglia. Neurovirol 2003, 9(2): 194-204.

15. Grinfeld E, Kennedy PG: Translation of varicella-zoster virus genes during human ganglionic latency. Virus Genes 2004, 29(3):317-319.

16. Spengler M, Niesen N, Grose C, Ruyechan WT, Hay J: Interactions among structural proteins of varicella zoster virus. Arch Virol Suppl 200I:7I-79.

17. Lynch JM, Kenyon TK, Grose C, Hay J, Ruyechan WT: Physical and functional interaction between the varicella zoster virus IE63 and IE62 proteins. Virology 2002, 302(I):7I-82.

18. Sommer MH, Zagha E, Serrano OK, Ku CC, Zerboni L, Baiker A, Santos R, Spengler M, Lynch J, Grose C, Ruyechan W, Hay J, Arvin AM: Mutational analysis of the repeated open reading frames, ORFs 63 and 70 and ORFs 64 and 69 , of varicella-zoster virus. JVirol 200I, 75( I 7):8224-8239.

19. Cohen JI, Cox E, Pesnicak L, Srinivas S, Krogmann T: The varicellazoster virus open reading frame 63 latency-associated protein is critical for establishment of latency. J Virol 2004, 78(2I): II833-II840.

20. Hood C, Cunningham AL, Slobedman B, Arvin AM, Sommer MH, Kinchington PR, Abendroth A: Varicella-zoster virus ORF63 inhibits apoptosis of primary human neurons. I Virol 2006, 80(2): $1025-103 \mid$.

21. Ambagala AP, Cohen JI: Varicella-Zoster virus IE63, a major viral latency protein, is required to inhibit the alpha interferon-induced antiviral response. J Virol 2007, 8I(I5):7844-785I.

22. Kost RG, Kupinsky H, Straus SE: Varicella-zoster virus gene 63: transcript mapping and regulatory activity. Virology 1995, 209(I):218-224.

23. Di Valentin E, Bontems S, Habran L, Jolois $\mathrm{O}$, Markine-Goriaynoff $\mathrm{N}$, Vanderplasschen A, Sadzot-Delvaux C, Piette J: Varicella-zoster 
virus IE63 protein represses the basal transcription machinery by disorganizing the pre-initiation complex. Biol Chem 2005, 386(3):255-267.

24. Habran L, Bontems S, Di Valentin E, Sadzot-Delvaux C, Piette J: Varicella-zoster virus IE63 protein phosphorylation by roscovitine-sensitive cyclin-dependent kinases modulates its cellular localization and activity. J Biol Chem 2005, 280(32):29|35-29|43.

25. Bontems S, Di Valentin E, Baudoux L, Rentier B, Sadzot-Delvaux C, Piette J: Phosphorylation of varicella-zoster virus IE63 protein by casein kinases influences its cellular localization and gene regulation activity. J Biol Chem 2002, 277(23):21050-21060.

26. Zuranski T, Nawar H, Czechowski D, Lynch JM, Arvin A, Hay J, Ruyechan WT: Cell-type-dependent activation of the cellular EF-Ialpha promoter by the varicella-zoster virus IE63 protein. Virology 2005, 338(I):35-42.

27. Desloges N, Rahaus M, Wolff MH: The varicella-zoster virusmediated delayed host shutoff: open reading frame 17 has no major function, whereas immediate-early 63 protein represses heterologous gene expression. Microbes Infect 2005.

28. Hoover SE, Cohrs RJ, Rangel ZG, Gilden DH, Munson P, Cohen Jl: Downregulation of varicella-zoster virus (VZV) immediateearly ORF62 transcription by VZV ORF63 correlates with virus replication in vitro and with latency. J Virol 2006, 80(7):3459-3468.

29. Hoberg JE, Yeung F, Mayo MW: SMRT derepression by the IkappaB kinase alpha: a prerequisite to NF-kappaB transcription and survival. Mol Cell 2004, I 6(2):245-255.

30. Jones JO, Arvin AM: Microarray Analysis of Host Cell Gene Transcription in Response to Varicella-Zoster Virus Infection of Human T Cells and Fibroblasts In Vitro and SCIDhu Skin Xenografts In Vivo. JVirol 2003, 77(2): I 268- 1280.

31. Jones JO, Arvin AM: Viral and cellular gene transcription in fibroblasts infected with small plaque mutants of varicellazoster virus. Antiviral Res 2005, 68(2):56-65.

32. Stevenson D, Xue M, Hay J, Ruyechan WT: Phosphorylation and nuclear localization of the varicella-zoster virus gene 63 protein. J Virol 1996, 70(I):658-662.

33. Ohgitani E, Kobayashi K, Takeshita K, Imanishi J: Induced expression and localization to nuclear-inclusion bodies of hsp70 in varicella-zoster virus-infected human diploid fibroblasts. Microbiol Immunol 1998, 42(I I):755-760.

34. Phillips B, Abravaya K, Morimoto RI: Analysis of the specificity and mechanism of transcriptional activation of the human hsp70 gene during infection by DNA viruses. I Virol 199|, 65(II):5680-5692.

35. Santoro MG: Heat shock proteins and virus replication: hsp70s as mediators of the antiviral effects of prostaglandins. Experientia 1994, 50(I I- I 2): 1039-1047.

36. White $E$, Spector $D$, Welch W: Differential distribution of the adenovirus EIA proteins and colocalization of EIA with the 70-kilodalton cellular heat shock protein in infected cells. J Virol 1988, 62(I I):4153-4I66.

37. Gasque P: Complement: a unique innate immune sensor for danger signals. Mol Immunol 2004, 4 I (II): 1089-1098.

38. Blom AM: Strategies developed by bacteria and virus for protection from the human complement system. Scand J Clin Lab Invest 2004, 64(5):479-496.

39. Mold C, Bradt BM, Nemerow GR, Cooper NR: Epstein-Barr virus regulates activation and processing of the third component of complement. J Exp Med 1988, 168(3):949-969.

40. Harris SL, Frank I, Yee A, Cohen GH, Eisenberg RJ, Friedman HM Glycoprotein $C$ of herpes simplex virus type I prevents complement-mediated cell lysis and virus neutralization. J Infect Dis 1990, I62(2):33।-337

41. Friedman HM, Wang L, Fishman NO, Lambris JD, Eisenberg RJ, Cohen $\mathrm{GH}$, Lubinski J: Immune evasion properties of herpes simplex virus type I glycoprotein gC. J Virol 1996, 70(7):4253-4260.

42. Karin M: How NF-kappaB is activated: the role of the IkappaB kinase (IKK) complex. Oncogene 1999, I 8(49):6867-6874.

43. Karin M, Ben-Neriah Y: Phosphorylation meets ubiquitination: the control of NF-[kappa]B activity. Annu Rev Immunol 2000 18:621-663.

44. Beinke S, Ley SC: Functions of NF-kappaB I and NF-kappaB2 in immune cell biology. Biochem J 2004, 382(Pt 2):393-409.
45. Gregory D, Hargett D, Holmes D, Money E, Bachenheimer SL: Efficient replication by herpes simplex virus type $I$ involves activation of the IkappaB kinase-lkappaB-p65 pathway. J Virol 2004, 78(24): I3582-13590.

46. DeMeritt IB, Milford LE, Yurochko AD: Activation of the NF-kappaB pathway in human cytomegalovirus-infected cells is necessary for efficient transactivation of the major immediateearly promoter. J Virol 2004, 78(9):4498-4507.

47. Montag C, Wagner J, Gruska I, Hagemeier C: Human Cytomegalovirus blocks TNF\{alpha\} and IL-I beta\}-mediated NF\{kappa\}B signaling. J Virol 2006.

48. Taylor RT, Bresnahan WA: Human cytomegalovirus immediate-early 2 protein IE86 blocks virus-induced chemokine expression. J Virol 2006, 80(2):920-928.

49. Wang JP, Kurt-Jones EA, Shin OS, Manchak MD, Levin MJ, Finberg $\mathrm{RW}$ : Varicella-zoster virus activates inflammatory cytokines in human monocytes and macrophages via Toll-like receptor 2. J Virol 2005, 79(20): | 2658-12666.

50. Rahaus M, Desloges N, Wolff MH: Replication of varicella-zoster virus is influenced by the levels of JNK/SAPK and p38/MAPK activation. J Gen Virol 2004, 85(Pt I 2):3529-3540.

51. Kent JR, Zeng PY, Atanasiu D, Gardner J, Fraser NW, Berger SL: During lytic infection herpes simplex virus type $I$ is associated with histones bearing modifications that correlate with active transcription. J Virol 2004, 78( I 8): 10178-10186.

52. Gu H, Liang Y, Mandel G, Roizman B: Components of the REST/ CoREST/histone deacetylase repressor complex are disrupted, modified, and translocated in HSV-I-infected cells. Proc Natl Acad Sci U S A 2005, I 02(2 I):757I-7576.

53. Poon AP, Gu H, Roizman B: ICPO and the US3 protein kinase of herpes simplex virus I independently block histone deacetylation to enable gene expression. Proc Natl Acad Sci U S A 2006, I 03(26):9993-9998.

54. Zhang $Y$, Jones $C$ : The bovine herpesvirus I immediate-early protein (bICP0) associates with histone deacetylase I to activate transcription. J Virol 200I, 75(20):957I-9578.

55. Zhang Y, Jiang Y, Geiser V, Zhou J, Jones C: Bovine herpesvirus I immediate-early protein (bICP0) interacts with the histone acetyltransferase $\mathrm{p} 300$, which stimulates productive infection and gC promoter activity. J Gen Virol 2006, 87(Pt 7): $|843-| 85 \mid$

56. Sirven A, Pflumio F, Zennou V, Titeux M, Vainchenker W, Coulombe L, Dubart-Kupperschmitt A, Charneau P: The human immunodeficiency virus type-I central DNA flap is a crucial determinant for lentiviral vector nuclear import and gene transduction of human hematopoietic stem cells. Blood 2000 , 96(13):4103-4110.

57. Naldini L, Blomer U, Gage FH, Trono D, Verma IM: Efficient transfer, integration, and sustained long-term expression of the transgene in adult rat brains injected with a lentiviral vector. Proc Natl Acad Sci U S A 1 996, 93(21): I I 382-I I 388.

58. Emi N, Friedmann T, Yee JK: Pseudotype formation of murine leukemia virus with the $\mathbf{G}$ protein of vesicular stomatitis virus. J Virol I99|, 65(3): | 202-1207.

59. [http://www.graphpad.com]

60. [http://abs.cit.nih.gov/geneexpression.html].

6I. Livak KJ, Schmittgen TD: Analysis of relative gene expression data using real-time quantitative PCR and the 2(-Delta Delta C(T)) Method. Methods 200I, 25(4):402-408. 